\title{
Riparian Bat Surveys in Eastern Montana
}

\author{
Prepared for: \\ USDI Bureau of Land Management \\ Montana State Office
}

By:

Paul Hendricks, Bryce Maxell, Susan Lenard, Coburn Currier and Joseph Johnson

Montana Natural Heritage Program

Natural Resource Information System

Montana State Library

April 2006

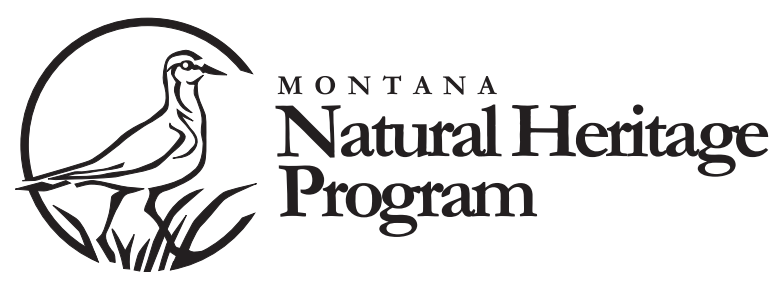





\title{
Riparian Bat Surveys in Eastern Montana
}

\author{
Prepared for: \\ USDI Bureau of Land Management \\ Montana State Office \\ 5001 Southgate Dr. \\ P. O. Box 36800 \\ Billings, MT 59107-6800
}

Agreement Number:

1422E930A960015

By:

Paul Hendricks, Bryce Maxell, Susan Lenard, Coburn Currier and Joseph Johnson
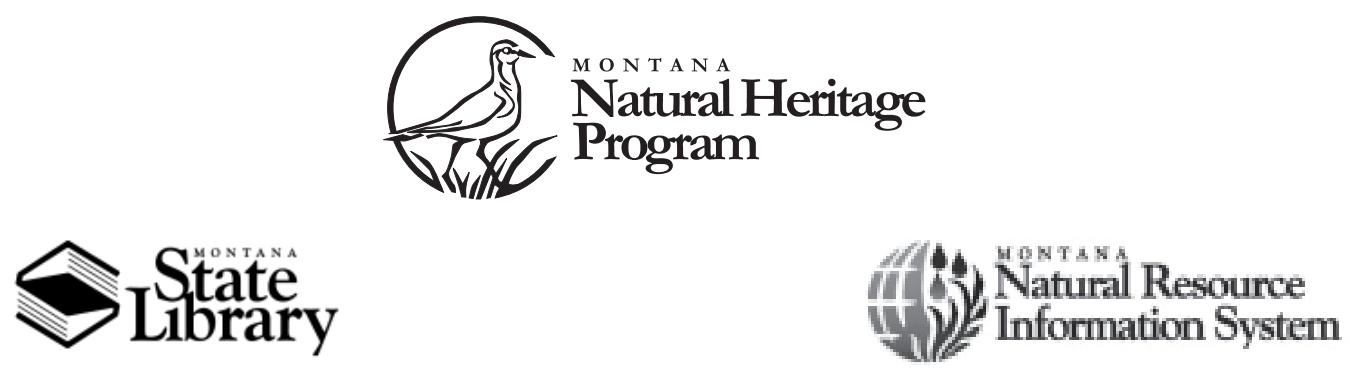

(c) 2006 Montana Natural Heritage Program

P.O. Box $201800 \bullet 1515$ East Sixth Avenue • Helena, MT 59620-1800 • 406-444-5354 
This document should be cited as follows:

Hendricks, P., B. Maxell, S. Lenard, C. Currier and J. Johnson. 2006. Riparian Bat Surveys in Eastern Montana. A report to the USDI Bureau of Land Management, Montana State Office. Montana Natural Heritage Program, Helena, Montana. 13 pp. plus appendices. 


\section{Executive Summary}

The distribution and status of bats in eastern Montana remain poorly documented, and the value of riparian corridors to bats in Montana has not been quantified. This is of conservation interest because management activities on prairie riparian corridors (e.g., timber harvest, impoundment and diversion of rivers and streams, livestock grazing) may have unintended consequences on habitats bats use for roosting and foraging, and may negatively impact bat populations. The Montana State Office of the BLM has designated five bat species as Sensitive: Pallid Bat (Antrozous pallidus), Townsend's Big-eared Bat (Corynorhinus townsendii), Spotted Bat (Euderma maculatum), Northern Myotis (Myotis septentrionalis), and Fringed Myotis (Myotis thysanodes). Each of these, along with Eastern Red Bat (Lasiurus borealis), is a state Species of Concern, and each has been documented in eastern Montana.

The Montana Office of the BLM recognized the need for additional documentation of bats in eastern Montana riparian corridors to inform management activity, and initiated bat surveys across the eastern prairies in 2003 to address this need. We surveyed non-randomly chosen riparian sites for bats along the lower Missouri and Yellowstone rivers and tributaries (Tongue and Powder rivers in particular). This approach was targeted at identifying species richness at survey sites and may be useful for developing and implementing a state grid-based system for long-term monitoring.

We surveyed 33 sites using mist nets, electronic detectors, or both. Twelve species of bats were detected during late-July to mid-September in 2003 and 2005. We captured 111 individuals at 13 sites, representing ten species: Townsend's Big-eared Bat at two sites, Big Brown Bat (Eptesicus fuscus) at six sites, Eastern Red Bat at one site, Hoary Bat (Lasiurus cinereus) at five sites, Silverhaired Bat (Lasionycteris noctivagans) at six sites, Western Small-footed Myotis ( $M$. ciliolabrum) at three sites, Western Long-eared Myotis (M. evotis) at four sites, Little Brown
Myotis (M. lucifugus) at five sites, Long-legged Myotis (M. volans) at one site, and Yuma Myotis (M. yumanensis) at three sites. Spotted Bat and Fringed Myotis were detected at three and two sites, respectively, but not captured. Townsend's Big-eared Bat and Eastern Red Bat were detected by vocalizations at two and nine additional sites, respectively. Prior to this survey, Eastern Red Bat was documented in Montana by only two verifiable records. No bats were identified at four sites, although presence of bats was noted at all but one of these. Bats at 16 sites were identified only by their vocalizations.

The 2003 and 2005 field surveys filled important gaps in documented distributions in Montana, adding 29 new county records, and underscored the importance of riparian corridors to bats in the eastern prairies. Existing bat records across the region clearly show that significant gaps in known distribution remain for all species, emphasizing the need for additional surveys. Large areas between the Missouri and Yellowstone rivers lack records of any bat species, and most records from the region are from the main river corridors. We recommend the BLM continue surveys in eastern Montana, possibly using a grid-based random sampling scheme stratified by ecoregion or Field Office that would allow for valid inferences of site occupancy rates across the selected stratum. This grid-based monitoring approach should be extended to all of Montana and coordinated with other partner agencies and organizations to guide effective bat management across the state.

Management for bats using riparian systems in eastern Montana should include retention of cottonwood stands whose ages range from decadent to newly regenerating. There is also a need to determine the response by bats to the presence and increase of exotic Russian olive (Elaeagnus angustifolia) and saltcedar (Tamarix spp.) in riparian corridors, as these two invasive phreatophytes seriously affect the ability of native cottonwoods to establish new stands and recruit at established stands. 


\section{ACKNOWLEDGEMENTS}

We thank the State Office of the BLM for supporting this project, which helped fill gaps in the known distributions of many bat species along the riparian corridors of eastern Montana. John Carlson, then of the Montana Natural Heritage Program and now with the BLM, was instrumental in promoting the original project and helped secure the funds for its implementation. We extend special thanks to Bruce Waage for inviting us to survey the bats on his river-bottom property near
Rosebud. Stormy weather dampened the potential results, but new distribution data were gathered nevertheless. Scott Blum, assistant biologist at the Montana Natural Heritage Program, entered survey data into the Point Observation Database (POD), facilitating the production of new distribution maps and the updating of element occurrence data in the Montana Natural Heritage Program's Biotics database. 


\section{TABLe OF Contents}

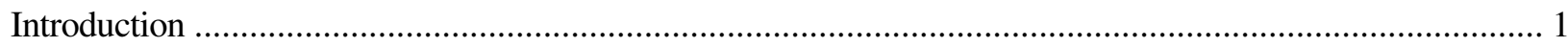

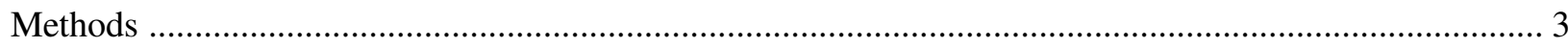

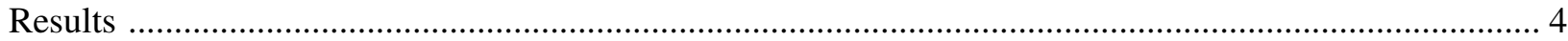

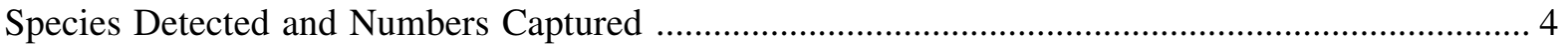

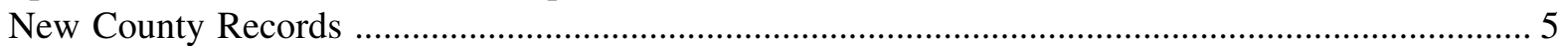

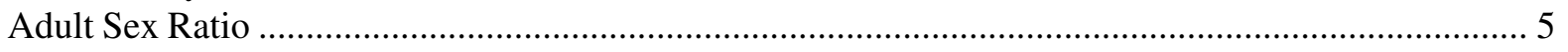

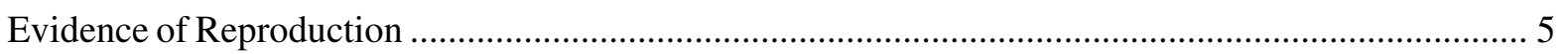

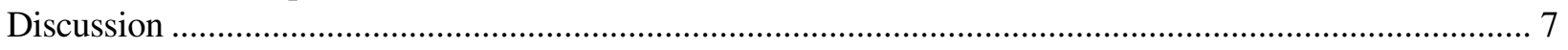

Overview and Importance of Prairie Riparian Corridors …........................................................... 7

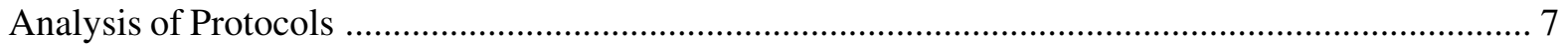

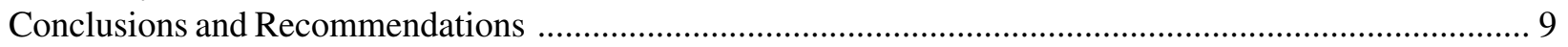

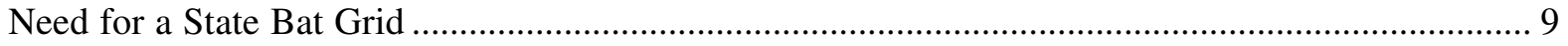

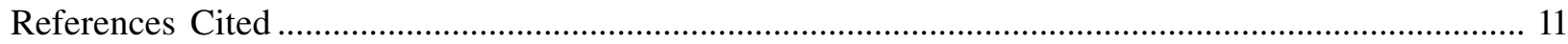

Appendix A. Global/State Rank Definitions

Appendix B. Riparian sites surveyed for bats during summer 2003 and 2005 in eastern Montana

Appendix C. Distribution maps for bats in Montana

\section{LiST OF TABLES}

Table 1. Number of sites where bats were detected and number of individuals captured ........................ 4 



\section{INTRODUCTION}

There has been growing concern in recent decades regarding the status of bats throughout North America, partly because of a general lack of basic natural history information (Hayes 2003), and also because a variety of habitats traditionally used by bats for roosting and foraging have been subjected to widespread disturbance, alteration, reduced availability, or complete removal (Fenton 1997, Pierson 1998). As a result, six species or subspecies of bats in the continental United States currently are classified as endangered under the United States Endangered Species Act of 1973 (O'Shea et al. 2003). Although none of these bat species occur in Montana, there is growing concern for a number of species that are known to inhabit the state.

Conservation and protection of roosts are important long-term management activities for many North American bat species (Sheffield et al. 1992). Unfortunately, conservation efforts for bats in Montana are often hampered by a lack of data on their habitat requirements. For example, the little data available from Montana on foraging and diet of bats have been obtained largely at water sources (Jones et al. 1973), with no knowledge of where the foraging bats are roosting. Conversely, studies of bat roosts in Montana (e.g., Worthington 1991a, 1991b, Hendricks et al. 2000, 2004) lack information on where and how far the roost members go to feed and drink. Nor have patterns of roost selection and fidelity (e.g., Sherwin et al. 2003) been studied in Montana, even though it is understood that suitable summer and winter roosts may limit the local and regional distribution and abundance of many temperate-zone bats (Humphrey 1975, Dobkin et al. 1995).

Most bat species use a variety of localized habitats for roosting, be they natural sites (e.g., caves, trees, rock crevices) or man-made sites (e.g., buildings, mines, bridges). Sites may be used only during specific seasons of the year, and then for different purposes. Recent research on bat roosts in Montana has followed the national pattern of inventorying and monitoring roosts in caves and abandoned mines (e.g., Worthington 1991a, 1991b,
Hendricks et al. 2000, 2004; Hendricks and Kampwerth 2001), and this remains an important activity for a state bat conservation plan. Nevertheless, sampling bats across the landscape at foraging sites continues to be critical for filling gaps in documented distributions, assessing relative abundance of local populations, and ultimately identifying roosts for these populations.

Riparian corridors cover $3 \%$ or less of the plains region of Montana (Knopf and Samson 1994), and provide almost the only forest cover in a huge expanse of grassland (Kudray et al. 2004). Most riparian corridors are degraded to a greater or lesser extent as a result of altered flood cycles and grazing impacts of livestock (Scott et al. 2003), or invasion of exotics that could replace cottonwood (Lesica 2001, Lesica and Miles 2001, Kudray et al 2004, Sexton et al. 2006). These anthropogenic habitat alterations continue to be of conservation concern because of the importance of riparian habitats for breeding birds and other wildlife species in prairie landscapes (Knopf and Samson 1994, Scott et al. 2003). Riparian corridors are preferred foraging habitat for bats inhabiting prairie landscapes (Holloway and Barclay 2000); most foraging activity at the local scale occurs within $1 \mathrm{~km}$ of riparian corridors and is associated with the presence of trees. Increased continuity in wooded riparian corridors is also one of the primary factors attributed to the westward expansion of the Eastern Pipistrelle (Pipistrellus subflavus) across the Great Plains to western South Dakota and eastern Wyoming (Geluso et al. 2005). Thus, protection of cottonwood stands and gallery forests, and wise management of riparian habitats in general, are a priority for maintaining wildlife diversity across the Great Plains.

Distribution and status of bats remain poorly documented across eastern Montana prairie landscapes. A summary of all existing bat records across the region clearly shows large distribution gaps for all species, further underscoring the need for additional surveys. This is of conservation interest because management activities on prairie landscapes may have unintended negative 
consequences on the habitats bats depend upon for roosting and foraging.

Five bat species in Montana are classified by the BLM as Sensitive (see Appendix A for Heritage Global and State Rank definitions): Pallid Bat (Antrozous pallidus) G5 S2, Townsend's Bigeared Bat (Corynorhinus townsendii) G4 S2, Spotted Bat (Euderma maculatum) G4 S2, Northern Myotis (Myotis septentrionalis) G4G5 S3, Fringed Myotis (Myotis thysanodes) G4 S2S3. Each is also a state Species of Concern (SOC) that has been documented in eastern Montana.

Additionally, Eastern Red Bat (Lasiurus borealis) G5 S2S3, a state SOC bat not classified at this time as Sensitive by the BLM, uses riparian habitat during migration through eastern Montana, and was reported in the state only twice with certainty (Foresman 2001) prior to the initiation of the BLM riparian surveys of 2003 and 2005. The Montana Office of the BLM recognized the desire for additional documentation of bats on BLM and adjacent lands along riparian corridors in eastern Montana to address inventory and monitoring needs that will guide informed management of riparian habitats. Therefore, bat surveys of eastern Montana riparian corridors were initiated in 2003 to address these conservation and management needs. 


\section{METHODS}

The primary objectives of the BLM riparian bat survey were to document bat species richness (number of species) at survey sites, and to fill in gaps in species distributions along eastern Montana riparian corridors, with a longer-term objective of establishing protocols for inferring sample unit occupancy by each species across the region. Surveys were conducted during late-July to midSeptember in 2003 and 2005 (see Appendix B). Most of the sites we sampled were along the Yellowstone River below Billings to the North Dakota state line, and along two major tributaries of the Yellowstone, the Tongue and Powder rivers. We also sampled locations along the Missouri River below Fort Peck, but land access to cottonwood stands is difficult along this portion of the Missouri, and only a few locations were visited. Survey sites spanned a narrow range of elevations: 1945-3300 $\mathrm{ft}$.

Sites chosen for survey were determined in the field by survey crews using land ownership maps and information provided by other sources (e.g., personal communications with other biologists). Most sites were on lands accessible to the public, but in those few cases where access was restricted, we obtained permission for entry prior to our survey. Sites usually contained features that might concentrate bat activity, most often water sources such as ponds, streams, or back channels bordered by riparian shrubs and trees, and cottonwood stands with mature trees, snags, and an open understory. Bats were captured using mist nets of various lengths and configurations; number of nets deployed varied from site to site. Nets were deployed at twilight and left open up to 3.5 hours, weather permitting, or until at least 1 hour passed without acoustic detections.

Species identification was based on published keys and species accounts (van Zyll de Jong 1985,
Nagorsen and Brigham 1993, Adams 2003). Standard measurements (weight, forearm length, ear length, sex, age, reproductive status) were obtained from each individual. Wing punch tissue samples were also collected from most captured bats, or until five punches/species were accumulated from each site. Tissue was taken using sterile procedures and stored in biopsy tubes containing desiccant. Tissue is to be used for genetic identification of species pairs that are difficult to distinguish in the field (especially Myotis lucifugus and M. yumanensis); genetic analysis had not been initiated at the time of this report.

Acoustic sampling is an important component of inventory and monitoring efforts (see Hayes 1997 and O'Farrell and Gannon 1999 for examples). The survey protocol we followed called for acoustic monitoring at each site using a Pettersson 240x detector. Vocalizations were downloaded in the field to a laptop computer, or to a $1 \mathrm{~GB}$ iRiver MP3 player and later converted and stored on a laptop. Vocalizations were analyzed using SonoBat ${ }^{\circledR}$ software (version 2.5; DNDesign); vocalizations were compared to reference calls and descriptions of call structure, and identified based on congruence with these. Unfortunately, equipment sometimes malfunctioned or was not available for all sites sampled. Nevertheless, we captured vocalizations at $73 \%$ of the 33 sites we sampled. Vocalization data were used only for species determinations, not inferences about relative abundance.

Data was recorded on standardized data sheets, and later transcribed to a Point Observation Database (POD) housed at the Montana Natural Heritage Program, Helena, where it is available for agency and public use. 


\section{RESULTS}

\section{Species Detected and Numbers Captured}

We sampled 33 sites for bats in the Missouri River and Yellowstone River drainages of eastern Montana during 2003 and 2005 (see Appendix B and map in Appendix C). Only mist nets were used at nine sites, only electronic detectors at another 11 sites, and both detection methods were used at the remaining 13 sites. Bats were captured at $59 \%$ (13) of the sites we netted (40\% of the total sites), and identified by vocalization at all sites (24) where we recorded calls; we detected the Spotted Bat by audible vocalization alone at one site where we netted but electronic detectors were not available. We failed to identify bats at three sites where we noted bat activity (no bats captured and no electronic detectors used to record vocalizations), and detected no bat activity at one site (see Appendix B). Thus, we detected bats at
$97 \%$ of the sites we sampled, and identified at least one species at $88 \%$.

We identified 12 species of bats through capture and/or recorded vocalization during our survey, representing $80 \%$ of the bat species known to occur in Montana (Foresman 2001); only Pallid Bat, California Myotis (Myotis californicus), and Northern Myotis were not detected, and California Myotis has not been reported from eastern Montana. We captured ten bat species, represented by 111 individuals, and identified two additional species based only on their vocalizations (Table 1). Of the 12 species we detected, Townsend's Big-eared Bat, Spotted Bat, Eastern Red Bat, and Fringed Myotis are Montana Animal Species of Concern (Montana Natural Heritage Program 2004), and all but the Eastern Red Bat are state BLM Sensitive species. We identified Silverhaired Bat (Lasionycteris noctivagans) and Little

Table 1. Number of sites where bats were detected, and total number of individuals captured, during riparian surveys in eastern Montana in late summer 2003 and 2005. Identity of bats with no captures is based on recorded vocalizations.

\begin{tabular}{|c||c|c|}
\hline & & \\
Species $^{\mathbf{a}}$ & Total Sites Detected & Total Captures $^{\mathbf{b}}$ \\
\hline COTO & 5 & 2,2 \\
\hline EPFU & 19 & 6,14 \\
\hline EUMA & 3 & 0,0 \\
\hline LABO & 10 & 1,1 \\
\hline LACI & 9 & 5,5 \\
\hline LANO & 22 & 6,11 \\
\hline MYCI & 17 & 3,4 \\
\hline MYEV & 11 & 4,12 \\
\hline MYLU & 22 & 5,53 \\
\hline MYTH & 2 & 0,0 \\
\hline MYVO & 12 & 1,1 \\
\hline MYYU & 3 & 3,8 \\
\hline
\end{tabular}

a Species codes: COTO (Corynorhinus townsendii, Townsend's Big-eared Bat), EPFU (Eptesicus fuscus, Big Brown Bat), EUMA (Euderma maculatum, Spotted Bat), LABO (Lasiurus borealis, Eastern Red Bat), LACI (Lasiurus cinereus, Hoary Bat), LANO (Lasionycteris noctivagans), MYCI (Myotis ciliolabrum, Western Small-footed Myotis), MYEV (Myotis evotis, Long-eared Myotis), MYLU (Myotis lucifugus, Little Brown Myotis), MYTH (Myotis thysanodes, Fringed Myotis), MYVO (Myotis volans, Longlegged Myotis), MYYU (Myotis yumanensis, Yuma Myotis).

${ }^{\mathrm{b}}$ Number of sites, number of individuals. 
Brown Myotis (Myotis lucifugus) at $67 \%$ of the sites (22 each), the two most widely identified species. Little Brown Myotis alone comprised nearly $50 \%$ of the individual bats we captured, followed by Big Brown Bat (Eptesicus fuscus) with $12.6 \%$, Long-eared Myotis (Myotis evotis) with $10.8 \%$, and Silver-haired Bat with $10.0 \%$ of the total capture (Table 1). The remaining eight species individually accounted for $<8 \%$ of the total number of bats captured. Spotted Bat and Fringed Myotis were not captured at any site, although we detected them at $9 \%$ and $6 \%$, respectively, of the total sites surveyed.

\section{New County Records}

Our riparian surveys in eastern Montana during 2003 and 2005 resulted in 29 new county records (14 based on captures, 15 based on vocalizations) in nine counties for ten bat species (see Appendix B and maps in Appendix C): Townsend's Big-eared Bat (Prairie), Eastern Red Bat (Powder River, Richland, Rosebud, Treasure, Yellowstone), Hoary Bat (McCone, Rosebud), Silver-haired Bat (Custer, Dawson, McCone, Richland, Rosebud, Treasure), Western Small-footed Myotis (Rosebud, Treasure), Long-eared Myotis (Prairie, Rosebud, Treasure), Little Brown Myotis (Prairie, Treasure), Fringed Myotis (Custer, Prairie), Long-legged Myotis (Custer, Prairie, Rosebud, Treasure), and Yuma Myotis (Treasure, Yellowstone). Treasure County received the most new records, with the addition of seven species (five capture, two vocalization), followed by Rosebud County with six species (three capture, three vocalization), and Prairie County with five species (two capture, three vocalization). The remaining seven counties had one to three new species each.

\section{Adult sex ratio}

Of the 111 bats we captured, 76 were adults. The ratio of males to females in this pooled adult sample was 1:2.5, or biased for females ( 22 males, 54 females). Only three species had as many as ten adults captured for examining the sex ratio of individual species; Big Brown Bat was represented by three males and eight females, Long-eared Myotis was represented by five males and five females, and Little Brown Myotis was represented by six males and 32 females. There were five or fewer adults for each of the remaining seven species in our pooled sample of captured bats.

\section{Evidence of Reproduction}

The best evidence of reproduction by a particular bat species is the presence of pregnant or lactating females. Testicular males are reproductively active, but their presence in a sample does not necessarily indicate reproduction near the survey site, while post-lactating females (with exposed but reduced nipples) and volant juveniles may have dispersed from adjacent areas. Nevertheless, the timing of our surveys (mostly August) precluded capturing pregnant females and reduced the likelihood of encountering lactating females, so our observations pertain primarily to post-lactating females, volant juveniles, and testicular males.

Included in our sample of captured bats were lactating females of three species, all from Yellowstone County: Big Brown Bat (31 July and 3 August), Little Brown Myotis (1 August), and Yuma Myotis (3 August). We captured postlactating females of six species between 31 July and 25 August: Silver-haired Bat, Western Smallfooted Myotis, Long-eared Myotis, Little Brown Myotis, Long-legged Myotis, and Yuma Myotis. We also captured volant juveniles of Big Brown Bat (3 August), Hoary Bat (1-8 August), Silverhaired Bat (1-22 August), Long-eared Myotis (2430 August), Little Brown Myotis (31 July-25 August), and Yuma Myotis (24-25 August). We found no evidence of reproduction by females, and captured no volant juveniles, for the remaining two species that we captured (Townsend's Big-eared Bat, Eastern Red Bat). However, we anticipate that reproduction by females of all species that we captured (with the possible exception of Eastern Red Bat) will eventually be documented, especially with additional survey effort earlier in the season. We captured testicular males of eight species: Townsend's Big-eared Bat (25 August), Big Brown Bat (24-25 August), Hoary Bat (31 July-23 August), Silver-haired Bat (24 August), Western Small-footed Myotis (24 August), Long-eared Myotis (24 August), Little Brown Myotis (24-25 August), and Yuma Myotis (24-25 August). 
To summarize, we documented local reproduction (lactating females) in three species, and possible local or regional reproduction (post-lactating females, volant juveniles, testicular males) in six additional species. Of the ten species we captured, only Eastern Red Bat (a single adult female) provided no evidence of reproduction in the region of capture, which is consistent with our understanding of its status as a migrant through eastern Montana. We cannot comment on the reproductive status of Spotted Bat and Fringed Myotis, which we documented only by vocalizations. 


\section{DisCUSSION}

\section{Overview and Importance of Prairie Riparian Corridors}

The 2003 and 2005 surveys of riparian corridors in eastern Montana helped fill distribution gaps, produced 29 first county records for ten bat species (Appendix C), including three first county records for two BLM Sensitive species (Townsend's Bigeared Bat, Fringed Myotis) and another five for a third state Species of Concern, the Eastern Red Bat; one of the Eastern Red Bat records was a non-reproductive adult female (weight: $16.5 \mathrm{~g}$, forearm: $41.7 \mathrm{~mm}$ ) netted at midnight on 11 August, 2005 near Culbertson, Richland County. There were only two reliable records for Eastern Red Bat in Montana prior to this survey (Foresman 2001). We captured Townsend's Big-eared Bat twice in August (in cottonwood stands near badlands-type terrain) and identified it by vocalization at three sites, one of these near the two capture sites. Other reports of this species from the lower Missouri and Yellowstone rivers are autumn and winter records (Swenson and Shanks 1979). Our survey suggests possible year-round use of the river corridors by Townsend's Big-eared Bat, but perhaps only where bluffs are nearby. In prairie landscapes, Big Brown Bat females sometimes establish maternity colonies in badland crevices adjacent to riparian corridors (Lausen and Barclay 2002). Our surveys also provided evidence that at least nine species of bats use or probably use prairie riparian landscapes for reproductive activities, and we documented $80 \%$ of the bat species known from Montana using riparian habitats in the eastern plains.

During our riparian surveys, we tended to catch adult female bats as often as, or more often than, adult males; this was the case for our combined sample of captured adults as well as for the three most abundant species in our adult sample (Big Brown Bat, Long-eared Myotis, Little Brown Myotis). A smaller sample of riparian bats, captured during an earlier survey of the Wild and Scenic Missouri River (Kudray et al. 2004), showed a slight bias for adult females, which is consistent with the riparian surveys we report here.
In contrast, a male bias has been noted in samples of Montana bats from upland or forested landscapes (Worthington 1991a, 1991b, Hendricks et al. 2000, 2004, Hendricks and Maxell 2005). Additional data are needed to determine the extent where this bias might exist, and under what conditions it is evident. Possibly, males outnumber females throughout the landscape, or perhaps they are easier to trap, but the bias for males in capture samples could result from differential habitat use by the sexes during the breeding season, as suggested by Bogan et al. (1996) and Cryan et al. (2000).

Our data indicate that adult females may use prairie riparian corridors more than males, perhaps because females are dependent on a more plentiful food supply and warmer, more stable roosting conditions for raising their young; their requirements are more likely to be met in prairie riparian habitats than in adjacent prairie landscapes (Holloway and Barclay 2000). Furthermore, maternity colonies of bats have been found relatively often in bridges in riparian corridors in some regions of eastern Montana (Hendricks et al. 2005), again suggesting that riparian habitats provide females with essential resources for raising young.

\section{Analysis of Protocols}

Acoustic technology has great potential to provide rapid assessment of species distributions over many sites and identify areas of significant concentrations of species and individuals. It also has an advantage over capture methods in requiring far less commitment of time and personnel. We consider acoustic monitoring an important component of future inventory and monitoring schemes, but it does not replace capture methods. There remains a need for recorded calls from individuals whose identity is definitive, through morphologic and genetic measurement, in order to build a library of reference calls for individual species from across the state. Furthermore, it is necessary to capture bats to determine their sex and monitor their reproductive status. The three sets of data (acoustic, morphologic, genetic) will provide future workers using acoustic monitoring the reference 
tools they need to identify and correct for regional differences in calls.

A useful sampling protocol for a broad-scale bat inventory would converge with that used in the Oregon Bat Grid, which incorporates elements of a typical state bird atlas project to help guide the sampling effort applied to each sample unit. In the Oregon scheme, the primary objective is to document all species on a list of expected species generated for each sample unit. Each sample unit is surveyed using multiple detection methods, but also is visited as many times (up to 12) as it takes to achieve the species richness goal. Even for roost monitoring of a species like Townsend's Bigeared Bat, there is so much detection variability during any single visit (due to a variety of environmental and sampling variables) that as many as nine visits to a site may be necessary to identify a non-roost (Sherwin et al. 2003). 


\section{Conclusions ANd Recommendations}

Knowledge of bats in Montana remains largely based on distribution records (e.g., Nicholson 1950, Hoffmann et al. 1969, Swenson 1970, Swenson and Bent 1977, Swenson and Shanks 1979, Shryer and Flath 1980, Foresman 2001), although there are a few published studies focusing on other aspects of the biology of Montana bats (e.g., Jones et al. 1973, Hendricks et al. 2000). In addition, several agency-funded projects have addressed information gaps that help guide management activities at the BLM Field Office or USFS Ranger District landscape scale (e.g., Worthington 1991a, 1991b, Hendricks and Kampwerth 2001, Hendricks et al. 2004, 2005, Hendricks and Maxell 2005).

Nevertheless, there are no studies from Montana addressing how bats use forested landscapes of different stand types, ages, and structural complexity (e.g., Thomas 1988, Kalcounis et al. 1999), nor studies of the significance of local landscape features to bats concentrated in riparian corridors of prairie regions (e.g., Holloway and Barclay 2000). These significant gaps in our understanding of bat use of Montana landscapes remain a major barrier to implementing effective conservations measures for protecting bat populations in the state.

Factors promoting structural diversity of cottonwood stands (natural geomorphic processes, limited grazing, control and eradication of exotic Russian olive and saltcedar) have been identified (Scott et al. 1997, Auble and Scott 1998, Lesica 2001, Lesica and Miles 2001, Scott et al. 2002, Kudray et al. 2004); proactive conservation of bats, as well as birds, across the Great Plains will be tied to the temporal and spatial structural diversity of riparian habitats. For bats using riparian corridors in prairie landscapes, it is of primary importance that cottonwood stands be retained, including decadent stands with large standing snags, as well as those with healthy cottonwood recruitment. Because male and female bats may differ in the sites they tend to use within local landscapes, information on potential differences in habitat use by males and females (and identification of significant resource needs by each sex) is necessary for monitoring bat populations, developing conservation plans for Species of Concern (e.g., Pierson et al. 1999), and effectively managing landscapes for bats.

The modification of landscapes is often considered the major cause of population fluctuations of many bat species. Measures for the conservation of bats frequently rely on knowledge of species-habitat relationships, and distribution maps are often used to assess a species' status. Thus, a thorough knowledge of bat distributions as they relate to habitat features is a critical base from which to direct and implement management and conservation activity. However, intensive population surveys of bats are difficult to conduct because of their nocturnal behavior and wide home ranges, and the difficulty of species identification while in flight. The latter problem is being addressed with improved technology, but intensive population surveys may remain beyond the scope of most conservation/management programs.

Modeling landscape features used by bats offers an alternative approach to multi-species population monitoring that may be useful for bat conservation at a landscape scale (Jaberg and Guisan 2001). To do modeling effectively, however, a large base of distribution records is necessary that sample all species and account for all activities (foraging, roosting, rearing young, mating, hibernating). This may be difficult to do across a landscape the size of Montana, but a systematic and standard method of data collection across the state will make habitat modeling a more realistic possibility.

\section{Need for a State Bat Grid}

Montana currently lacks any statewide scheme for bat inventory and monitoring. This will be a crucial component for effective implementation of the state bat conservation plan now under development. The objectives of a state bat grid are 1) to inventory the presence of bat species using a standardized survey effort and sampling unit across the survey region, 2) collect baseline data on acoustic, morphologic, and genetic characteristics that serve as reference for bat species 
identification, and 3) to provide a baseline inventory for repeat surveys to assess change over time. Inventorying and monitoring bat distributions and trends at this scale will place us in a better position to address conservation issues as they arise. To date, none of these objectives has been thoroughly addressed in Montana, although the 2005 survey of selected Districts of the Northern Region of USFS lands (see Hendricks and Maxell 2005) was an admirable pilot effort towards satisfying these objectives.

We recommend the development of a bat grid applied to all of Montana. Simply determining whether or not a species is present or breeding in a grid cell is a valuable way of monitoring the distribution and status of species over time relative to a variety of associated variables (Hayek 1994; Olson et al. 1997). The Oregon Bat Grid offers a suitable model scheme from which to design a state bat grid, although modification of some protocols may be necessary for application to Montana, due to limitations in personnel and agency support, as well as land access issues.

It is beyond the scope of this report to explore the details of what comprises a state bat grid. Nevertheless, the scheme that is eventually developed should include a hierarchical scale of data collection that allows inference of grid cell occupancy rates. Inference may best be regarded as being informative relative to management actions at broader spatial scales. However, this is also an ideal approach for raising red flags at individual habitat patches or local regions (and grid cells) so that these rapid assessment surveys can be followed up with more detailed studies of a population's status. 


\section{References Cited}

Adams, R. A. 2003. Bats of the Rocky Mountain West. University Press of Colorado, Boulder, CO. 289 pp.

Auble, G. T., and M. L. Scott. 1998. Fluvial disturbance patches and cottonwood recruitment along the upper Missouri River, Montana. Wetlands 18:546-556.

Bogan, M. A., J. G. Osborne, and J. A. Clarke. 1996. Observations on the bats at Badlands National Park, South Dakota. Prairie Naturalist 28:115-123.

Cryan, P. M., M. A. Bogan, and J. S. Altenbach. 2000. Effect of elevation on distribution of female bats in the Black Hills, South Dakota. Journal of Mammalogy 81:719725 .

Dobkin, D. S., R. D. Gettinger, and M. G. Gerdes. 1995. Springtime movements, roost use, and foraging activity of Townsend's Bigeared Bat (Plecotus townsendii) in central Oregon. Great Basin Naturalist 55:315321.

Fenton, M. B. 1997. Science and the conservation of bats. Journal of Mammalogy 78:1-14.

Foresman, K. R. 2001. The wild mammals of Montana. American Society of Mammalogists, Special Publication No. 12. $278 \mathrm{pp}$.

Geluso, K., T. R. Mollhagen, J. M. Tigner, and M. A. Bogen. 2005. Westward expansion of the Eastern Pipistrelle (Pipistrellus subflavus) in the United States, including new records from New Mexico, South Dakota, and Texas. Western North American Naturalist 65:405-409.
Hayek, L. C. 1994. Analysis of amphibian biodiversity data. Pp. 207-269. In: W. R. Heyer, M. A. Donnelly, R. W. McDiarmid, L. C. Hayek, and M. S. Foster (eds). Measuring and monitoring biological diversity: standard methods for amphibians. Smithsonian Institution Press. Washington, D.C. $364 \mathrm{pp}$.

Hayes, J. P. 1997. Temporal variation in activity of bats and the design of echolocationmonitoring studies. Journal of Mammalogy 78:514-524.

Hayes, J. P. 2003. Habitat ecology and conservation of bats in western coniferous forests. Pp. 81-119 In Mammal community dynamics: management and conservation in the coniferous forests of western North America (C. J. Zabel and R. G. Anthony, eds.). Cambridge University Press, Cambridge, UK. 709 pp.

Hendricks, P., C. Currier, and J. Carlson. 2004. Bats of the BLM Billings Field Office in south-central Montana, with emphasis on the Pryor Mountains. Report to Bureau of Land Management Billings Field Office. Montana Natural Heritage Program, Helena, MT. 19 pp. + appendices.

Hendricks, P., D. L. Genter, and S. Martinez. 2000. Bats of Azure Cave and the Little Rocky Mountains, Montana. Canadian Field-Naturalist 114:89-97.

Hendricks, P., and D. Kampwerth. 2001. Roost environments for bats using abandoned mines in southwestern Montana: a preliminary assessment. Report to the U.S. Bureau of Land Management. Montana Natural Heritage Program, Helena. 19 pp. 
Hendricks, P., S. Lenard, C. Currier, and J. Johnson. 2005. Bat use of highway bridges in south-central Montana. Report to Montana Department of Transportation. Montana Natural Heritage Program, Helena. $31 \mathrm{pp}$.

Hendricks, P., and B. A. Maxell. 2005. Bat surveys on USFS Northern Region lands in Montana: 2005. Report to the USDA Forest Service, Northern Region. Montana Natural Heritage Program, Helena, MT. 12 pp. + appendices.

Hoffmann, R. S., D. L. Pattie, and J. F. Bell. 1969. The distribution of some mammals in Montana. II. Bats. Journal of Mammalogy 50:737-741.

Holloway, G. L., and R. M. R. Barclay. 2000. Importance of prairie riparian zones to bats in southeastern Alberta. Écoscience 7:115122.

Humphrey, S. R. 1975. Nursery roosts and community diversity of Nearctic bats. Journal of Mammalogy 56:321-346.

Jaberg, C., and A. Guisan. 2001. Modelling the distribution of bats in relation to landscape structure in a temperate mountain environment. Journal of Applied Ecology 38:1169-1181.

Jones, J. K., Jr., R. P. Lampe, C. A. Spenrath, and T. H. Kunz. 1973. Notes on the distribution and natural history of bats in southeastern Montana. Occasional Papers, The Museum, Texas Tech University 15:1-12.

Kalcounis, M. C., K. A. Hobson, R. M. Brigham, and K. R. Hecker. 1999. Bat activity in the boreal forest: importance of stand type and vertical strata. Journal of Mammalogy 80:673-682.
Knopf, F. L., and F. B. Samson. 1994. Scale perspectives on avian diversity in western riparian ecosystems. Conservation Biology 8:669-676.

Kudray, G., P. Hendricks, E. Crowe, and S. Cooper. 2004. Riparian forests of the Wild and Scenic Missouri River: ecology and management. Report to the Lewistown Field Office, Bureau of Land Management. Montana Natural Heritage Program, Helena, MT. 29 pp. + appendices.

Lausen, C. L., and R. M. R. Barclay. 2002. Roosting behaviour and roost selection of female big brown bats (Eptesicus fuscus) roosting in rock crevices in southeastern Alberta. Canadian Journal of Zoology 80:1069-1076.

Lesica, P. 2001. Natural history and invasion of Russian olive along eastern Montana rivers. Western North American Naturalist 61:1-10.

Lesica, P., and S. Miles. 2001. Tamarisk growth at the northern margin of its naturalized range in Montana, USA. Wetlands 21:240246.

Nagorsen, D. W., and R. M. Brigham. 1993. Bats of British Columbia. UBC Press. Vancouver, BC. $164 \mathrm{p}$.

Nicholson, A. J. 1950. A record of the Spotted Bat (Euderma maculata) for Montana. Journal of Mammalogy 31:197.

O'Farrell, M. J., and W. L. Gannon. 1999. A comparison of acoustic versus capture techniques for the inventory of bats. Journal of Mammalogy 80:24-30.

Olson, D. H., W. P. Leonard, and R. B. Bury (eds). 1997. Sampling amphibians in lentic habitats: methods and approaches for the Pacific Northwest. Northwest Fauna 4:1134. 
O'Shea, T. J., M. A. Bogan, and L. E. Ellison. 2003. Monitoring trends in bat populations of the United States and territories: status of the science and recommendations for the future. Wildlife Society Bulletin 31:1629.

Pierson, E. D. 1998. Tall trees, deep holes, and scarred landscapes: conservation biology of North American bats. Pp. 309-325, In Bat biology and conservation (T. H. Kunz and P. A. Racey, eds.). Smithsonian Institution Press, Washington, DC. 365 pp.

Pierson, E. D., and 14 others. 1999. Species conservation assessment and strategy for Townsend's Big-eared Bat (Corynorhinus townsendii townsendii and Corynorhinus townsendii pallescens). Idaho Conservation Effort, Idaho Department of Fish and Game, Boise, ID. 68 pp.

Scott, M. L., G. T. Auble, and J. M. Friedman. 1997. Flood dependency of cottonwood establishment along the Missouri River, Montana, USA. Ecological Applications 7:677-690.

Scott, M. L., S. K. Skagen, and M. F. Merigliano. 2003. Relating geomorphic change and grazing to avian communities in riparian forests. Conservation Biology 17:284-296.

Sexton, J. P., A. Sala, and K. Murray. 2006. Occurrence, persistence, and expansion of saltcedar (Tamarix spp.) populations in the Great Plains of Montana. Western North American Naturalist 66:1-11.

Sheffield, S. R., J. H. Shaw, G. A. Heidt, and L. R. McClenaghan. 1992. Guidelines for the protection of bat roosts. Journal of Mammalogy 73:707-710.

Sherwin, R. E., W. L. Gannon, and J. S. Altenbach. 2003. Managing complex systems simply: understanding inherent variation in the use of roosts by Townsend's Big-eared Bat. Wildlife Society Bulletin 31:62-72.
Shryer, J. and D. L. Flath. 1980. First record of the Pallid Bat (Antrozous pallidus) from Montana. Great Basin Naturalist 40:115.

Swenson, J. E. 1970. Notes on the distribution of Myotis leibii in eastern Montana. Blue Jay 28:173-174.

Swenson, J. E., and J. C. Bent. 1977. The bats of Yellowstone County, southcentral Montana. Proceedings of the Montana Academy of Sciences 37:82-84.

Swenson, J. E., and G. F. Shanks, Jr. 1979. Noteworthy records of bats from northeastern Montana. Journal of Mammalogy 60:650-652.

Thomas, D. W. 1988. The distribution of bats in different ages of Douglas-fir forests. Journal of Wildlife Management 52:619626.

van Zyll de Jong, C. G. 1985. Handbook of Canadian mammals. 2. Bats. National Museum of Natural Sciences. Ottawa, ON. 212 p.

Worthington, D. J. 1991a. Abundance and distribution of bats in the Pryor Mountains of south central Montana and northeastern Wyoming. Report for the Bureau of Land Management Billings Resource Area and Custer National Forest. Montana Natural Heritage Program, Helena, MT. 23 pp.

Worthington, D. J. 1991b. Abundance, distribution, and sexual segregation of bats in the Pryor Mountains of south central Montana. Master's Thesis, University of Montana, Missoula, MT. 41 pp. 



\section{Appendix A. Global/State Rank Definitions}





\section{Heritage Program Ranks}

The international network of Natural Heritage Programs employs a standardized ranking system to denote global (range-wide) and state status. Species are assigned numeric ranks ranging from 1 to 5, reflecting the relative degree to which they are "at-risk". Rank definitions are given below. A number of factors are considered in assigning ranks - the number, size and distribution of known "occurrences" or populations, population trends (if known), habitat sensitivity, and threat. Factors in a species' life history that make it especially vulnerable are also considered (e.g., dependence on a specific pollinator).

Global Rank Definitions (NatureServe 2003)

G1 Critically imperiled because of extreme rarity and/or other factors making it highly vulnerable to extinction

G2 Imperiled because of rarity and/or other factors making it vulnerable to extinction

G3 Vulnerable because of rarity or restricted range and/or other factors, even though it may be abundant at some of its locations

G4 Apparently secure, though it may be quite rare in parts of its range, especially at the periphery

G5 Demonstrably secure, though it may be quite rare in parts of its range, especially at the periphery

T1-5 Infraspecific Taxon (trinomial) - The status of infraspecific taxa (subspecies or varieties) are indicated by a "T-rank" following the species' global rank

\section{State Rank Definitions}

S1

S2

S3

S4

S5

At high risk because of extremely limited and potentially declining numbers, extent and/or habitat, making it highly vulnerable to extirpation in the state At risk because of very limited and potentially declining numbers, extent and/or habitat, making it vulnerable to extirpation in the state

S3 Potentially at risk because of limited and potentially declining numbers, extent and/or habitat, even though it may be abundant in some areas

S4 Uncommon but not rare (although it may be rare in parts of its range), and usually widespread. Apparently not vulnerable in most of its range, but possibly cause for long-term concern Common, widespread, and abundant (although it may be rare in parts of its range). Not vulnerable in most of its range

\section{COMBination RANKS}

G\#G\# or S\#S\# Range Rank-A numeric range rank (e.g., G2G3) used to indicate uncertainty about the exact status of a taxon

\section{QUALIFIERS}

NR

Not ranked

Questionable taxonomy that may reduce conservation priority-Distinctiveness of this entity as a taxon at the current level is questionable; resolution of this uncertainty may result in change from a species to a subspecies or hybrid, or inclusion of this taxon in another taxon, with the resulting taxon having a lower-priority (numerically higher) conservation status rank 
Presumed Extinct-Species believed to be extinct throughout its range. Not located despite intensive searches of historical sites and other appropriate habitat, and virtually no likelihood that it will be rediscovered

H Possibly Extinct-Species known from only historical occurrences, but may never-theless still be extant; further searching needed

Unrankable - Species currently unrankable due to lack of information or due to substantially conflicting information about status or trends

HYB Hybrid-Entity not ranked because it represents an interspecific hybrid and not a species

Inexact Numeric Rank-Denotes inexact numeric rank

$\mathrm{C}$

Captive or Cultivated Only-Species at present is extant only in captivity or cultivation, or as a reintroduced population not yet established

Accidental-Species is accidental or casual in Montana, in other words, infrequent and outside usual range. Includes species (usually birds or butterflies) recorded once or only a few times at a location. A few of these species may have bred on the one or two occasions they were recorded

Z Zero Occurrences-Species is present but lacking practical conservation concern in Montana because there are no definable occurrences, although the taxon is native and appears regularly in Montana

Potential-Potential that species occurs in Montana but no extant or historic occurrences are accepted

R Reported-Species reported in Montana but without a basis for either accepting or rejecting the report, or the report not yet reviewed locally. Some of these are very recent discoveries for which the program has not yet received first-hand information; others are old, obscure reports

SYN Synonym - Species reported as occurring in Montana, but the Montana Natural Heritage Program does not recognize the taxon; therefore the species is not assigned a rank

A rank has been assigned and is under review. Contact the Montana Natural Heritage Program for assigned rank

B Breeding - Rank refers to the breeding population of the species in Montana 


\section{Appendix B. Riparian Sites Surveyed for Bats During Summer 2003 ANd 2005 in Eastern Montana}





\begin{tabular}{|c|c|c|c|c|c|}
\hline County & $\begin{array}{c}\text { UTM } \\
\text { NAD 27 }\end{array}$ & Site Name & $\begin{array}{c}\text { Elev } \\
(f t)\end{array}$ & Date & Bats Detected $^{\mathrm{a}}$ \\
\hline Yellowstone & (13) 267671E; 5096876N & $\begin{array}{l}\text { Pompey's Pillar, } \\
\text { Picnic Grove }\end{array}$ & 2840 & $\begin{array}{c}26 \text { Aug } \\
03\end{array}$ & Bats present, but none ID'd \\
\hline Yellowstone & (12) $731876 \mathrm{E} ; 5097784 \mathrm{~N}$ & Pompey's Pillar & 2840 & $\begin{array}{l}2 \text { Sep } 03 \\
16 \text { Sep } \\
03\end{array}$ & $\begin{array}{l}\text { Bats present, but none ID'd } \\
\text { V: EUMA, MYLU }\end{array}$ \\
\hline Richland & (13) $558517 \mathrm{E} ; 5269078 \mathrm{~N}$ & Seven Sisters WMA & 1945 & $\begin{array}{c}27 \text { Aug } \\
03\end{array}$ & V: EPFU, LABO, LANO, MYEV, MYLU \\
\hline Richland & (13) 557701E; 5269224N & Seven Sisters WMA & 1945 & $\begin{array}{l}28 \text { Aug } \\
03\end{array}$ & V: MYCI, MYLU \\
\hline Prairie & (13) $467255 \mathrm{E} ; 5176019 \mathrm{~N}$ & Powder River Depot & 2255 & $\begin{array}{l}29 \text { Aug } \\
03\end{array}$ & V: COTO, EPFU, LANO, MYCI, MYEV \\
\hline Prairie & (13) 466983E; 5176761N & Powder River Depot & 2255 & $\begin{array}{l}30 \text { Aug } \\
03 \\
18 \text { Sep } \\
03\end{array}$ & $\begin{array}{l}\text { V: MYLU } \\
\text { C: MYCI (1), MYEV (8) } \\
\text { V: MYEV, MYLU, MYTH, MYVO }\end{array}$ \\
\hline Custer & (13) 431387E; 5138413N & Fort Keogh & 2360 & $\begin{array}{l}31 \text { Aug } \\
03\end{array}$ & V: EPFU, LABO, LANO, MYEV, MYTH \\
\hline Treasure & (13) $321415 \mathrm{E} ; 5126998 \mathrm{~N}$ & $\begin{array}{l}\text { Isaac Homestead } \\
\text { WMA }\end{array}$ & 2450 & 1 Sep 03 & Bats present, but none ID'd \\
\hline Yellowstone & (12) 707479E; 5084020N & Huntley & 3021 & $\begin{array}{c}31 \mathrm{Jul} \\
05\end{array}$ & $\begin{array}{l}\text { C: EPFU (3), LACI (1), LANO (1), MYLU } \\
\text { (2) }\end{array}$ \\
\hline Yellowstone & (13) 293452E; 5109520N & Buffalo Gulch & 2798 & $\begin{array}{l}1 \mathrm{Aug} \\
05\end{array}$ & $\begin{array}{l}\text { V: EUMA } \\
\text { C: EPFU (2), LACI (1), LANO (2), MYLU } \\
(17)\end{array}$ \\
\hline Yellowstone & (13) 301638E; 5113212N & Custer BLM & 2724 & $\begin{array}{c}3 \text { Aug } \\
05\end{array}$ & $\begin{array}{l}\text { C: EPFU (6), LACI (1), LANO (3), MYLU } \\
\text { (4), MYYU (1) }\end{array}$ \\
\hline McCone & (13) $402888 \mathrm{E} ; 5321531 \mathrm{~N}$ & below Fort Peck & 2033 & $\begin{array}{l}8 \text { Aug } \\
05\end{array}$ & C: LACI (1), LANO (1) \\
\hline McCone & (13) 460258E; 5323566N & $\begin{array}{c}\text { Wolf Point } \\
\text { Gauging Station }\end{array}$ & 2058 & $\begin{array}{l}9 \text { Aug } \\
05\end{array}$ & Bats present, but none ID'd \\
\hline
\end{tabular}




\begin{tabular}{|c|c|c|c|c|c|}
\hline County & $\begin{array}{c}\text { UTM } \\
\text { NAD 27 } \\
\end{array}$ & Site Name & $\begin{array}{c}\text { Elev } \\
(\mathbf{f t})\end{array}$ & Date & Bats Detected $^{\mathrm{a}}$ \\
\hline McCone & (13) 483798E; 5322416N & Red Water River & 2021 & $\begin{array}{l}10 \text { Aug } \\
05\end{array}$ & No bats detected \\
\hline Richland & (13) 527173E; 5328171N & SW of Culbertson & 1948 & $\begin{array}{l}11 \text { Aug } \\
05\end{array}$ & C: LABO (1) \\
\hline Rosebud & (13) $382616 \mathrm{E} ; 5126838 \mathrm{~N}$ & Waage Property & 2430 & $\begin{array}{l}22 \text { Aug } \\
05\end{array}$ & $\begin{array}{l}\text { V: COTO, EPFU, LABO, MYLU } \\
\text { C: EPFU (1), LANO (2) }\end{array}$ \\
\hline Rosebud & (13) 352879E; 5127744N & W of Forsyth & 2600 & $\begin{array}{l}23 \text { Aug } \\
05\end{array}$ & $\begin{array}{l}\text { V: LABO, LANO } \\
\text { C: LACI (1), MYEV (1) }\end{array}$ \\
\hline Treasure & (13) 320162E; 5124933N & Myers BLM & 2683 & $\begin{array}{l}24 \text { Aug } \\
05\end{array}$ & $\begin{array}{l}\text { V: LABO, LANO, MYCI, MYEV, MYLU, } \\
\text { MYVO } \\
\text { C: LANO (1), MYEV (2), MYLU (9), } \\
\text { MYVO (1), MYYU (2) }\end{array}$ \\
\hline Yellowstone & (13) 308203E; 5114494N & Government Island & 2721 & $\begin{array}{l}25 \text { Aug } \\
05\end{array}$ & $\begin{array}{l}\text { V: EPFU, EUMA, LABO, LACI, LANO, } \\
\text { MYCI, MYLU } \\
\text { C: EPFU (1), MYLU (21), MYYU (5) }\end{array}$ \\
\hline Custer & (13) $479549 \mathrm{E} ; 5121063 \mathrm{~N}$ & Mizpah BLM & 2537 & $\begin{array}{l}30 \text { Aug } \\
05\end{array}$ & V: EPFU, MYCI, MYLU, MYVO \\
\hline Custer & (13) 477966E; 5129177N & $\mathrm{N}$ of Mizpah & 2473 & $\begin{array}{c}30-31 \\
\text { Aug } 05\end{array}$ & V: EPFU, LANO, MYCI, MYEV, MYVO \\
\hline Custer & (13) 487381E; 5109808N & Cut Coulee & 2603 & $\begin{array}{l}31 \text { Aug } \\
05\end{array}$ & $\begin{array}{l}\text { V: COTO, EPFU, LABO, LACI, LANO, } \\
\text { MYCI, MYEV, MYLU, MYVO }\end{array}$ \\
\hline Powder River & (13) 475354E; 5004609N & Belle Creek & 3205 & 1 Sep 05 & V: EPFU, LACI, MYCI \\
\hline Powder River & (13) 474003E; 4994460N & Biddle & 3298 & 1 Sep 05 & V: EPFU, LABO, LANO, MYLU, MYVO \\
\hline Powder River & (13) 458382E; 5021446N & SW of Broadus & 3134 & 2 Sep 05 & $\begin{array}{l}\text { V: EPFU, LABO, LACI, LANO, MYCI, } \\
\text { MYLU, MYVO }\end{array}$ \\
\hline Dawson & (13) 497931E; 5193899N & Bad Route Creek & 2250 & $\begin{array}{l}23 \text { Aug } \\
05\end{array}$ & $\begin{array}{l}\text { V: EPFU, LANO, MYLU, MYVO } \\
\text { C: MYCI (1) }\end{array}$ \\
\hline Prairie & (13) 468061E; 5180774N & $\begin{array}{l}\text { Calypso Fishing } \\
\text { Access }\end{array}$ & 2190 & $\begin{array}{l}24 \text { Aug } \\
05\end{array}$ & $\begin{array}{l}\text { V: EPFU, LANO, MYCI, MYLU, MYVO } \\
\text { C: COTO (1), EPFU (1), MYCI (2), MYEV } \\
\text { (1) }\end{array}$ \\
\hline Prairie & (13) 458155E; 5167171N & $\mathrm{CoCo}$ & 2262 & $\begin{array}{l}25 \text { Aug } \\
05\end{array}$ & $\begin{array}{l}\text { V: COTO, EPFU, LANO, MYCI, MYVO } \\
\text { C: COTO (1) }\end{array}$ \\
\hline
\end{tabular}




\begin{tabular}{|c|c|c|c|c|c||}
\hline County & $\begin{array}{c}\text { UTM } \\
\text { NAD 27 }\end{array}$ & Site Name & $\begin{array}{c}\text { Elev } \\
\text { (ft) }\end{array}$ & Date & Bats Detected $^{\mathbf{a}^{2}}$ \\
\hline \hline Custer & $(13) 436764 \mathrm{E} ; 5143026 \mathrm{~N}$ & $\begin{array}{c}\text { Progue State } \\
\text { Recreation Area }\end{array}$ & 2390 & $\begin{array}{c}29 \text { Aug } \\
05\end{array}$ & V: EPFU, MYCI, MYLU \\
\hline Powder River & $(13) 402304 \mathrm{E} ; 5017988 \mathrm{~N}$ & $\begin{array}{c}\text { Cow Creek } \\
\text { Reservoir }\end{array}$ & 3850 & $\begin{array}{c}30 \text { Aug } \\
05\end{array}$ & V: LANO, MYCI, MYLU, MYVO \\
\hline Rosebud & (13) 400456E; 5050016N & Ashland & 2990 & $\begin{array}{c}31 \text { Aug } \\
05\end{array}$ & V: LANO, MYCI, MYLU \\
\hline Rosebud & (13) 405343E; 5076761N & N of Brandenberg & 2830 & $\begin{array}{c}31 \text { Aug } \\
05\end{array}$ & V: EPFU, LANO, MYCI, MYLU, MYVO \\
\hline Custer & (13) 442235E; 5121393N & $\begin{array}{c}\text { 12-mile Dam } \\
\text { Fishing Access }\end{array}$ & 2460 & $\begin{array}{c}31 \text { Aug- } \\
1 \text { Sep 05 }\end{array}$ & V: LANO, MYCI, MYEV, MYLU \\
\hline
\end{tabular}

${ }^{a}$ Identification codes: V: vocalization, C: captured. Species codes: COTO (Corynorhinus townsendii, Townsend's Big-eared Bat), EPFU (Eptesicus fuscus, Big Brown Bat), EUMA (Euderma maculatum, Spotted Bat), LABO (Lasiurus borealis, Eastern Red Bat),

LACI (Lasiurus cinereus, Hoary Bat), LANO (Lasionycteris noctivagans), MYCI (Myotis ciliolabrum, Western Small-footed Myotis), MYEV (Myotis evotis, Western Long-eared Myotis), MYLU (Myotis lucifugus, Little Brown Myotis), MYTH (Myotis thysanodes, Fringed Myotis), MYVO (Myotis volans, Long-legged Myotis), MYYU (Myotis yumanensis, Yuma Myotis). 

Appendix C. Distribution Maps for Bats in Montana 

Montana Bat Distribution Data Sources

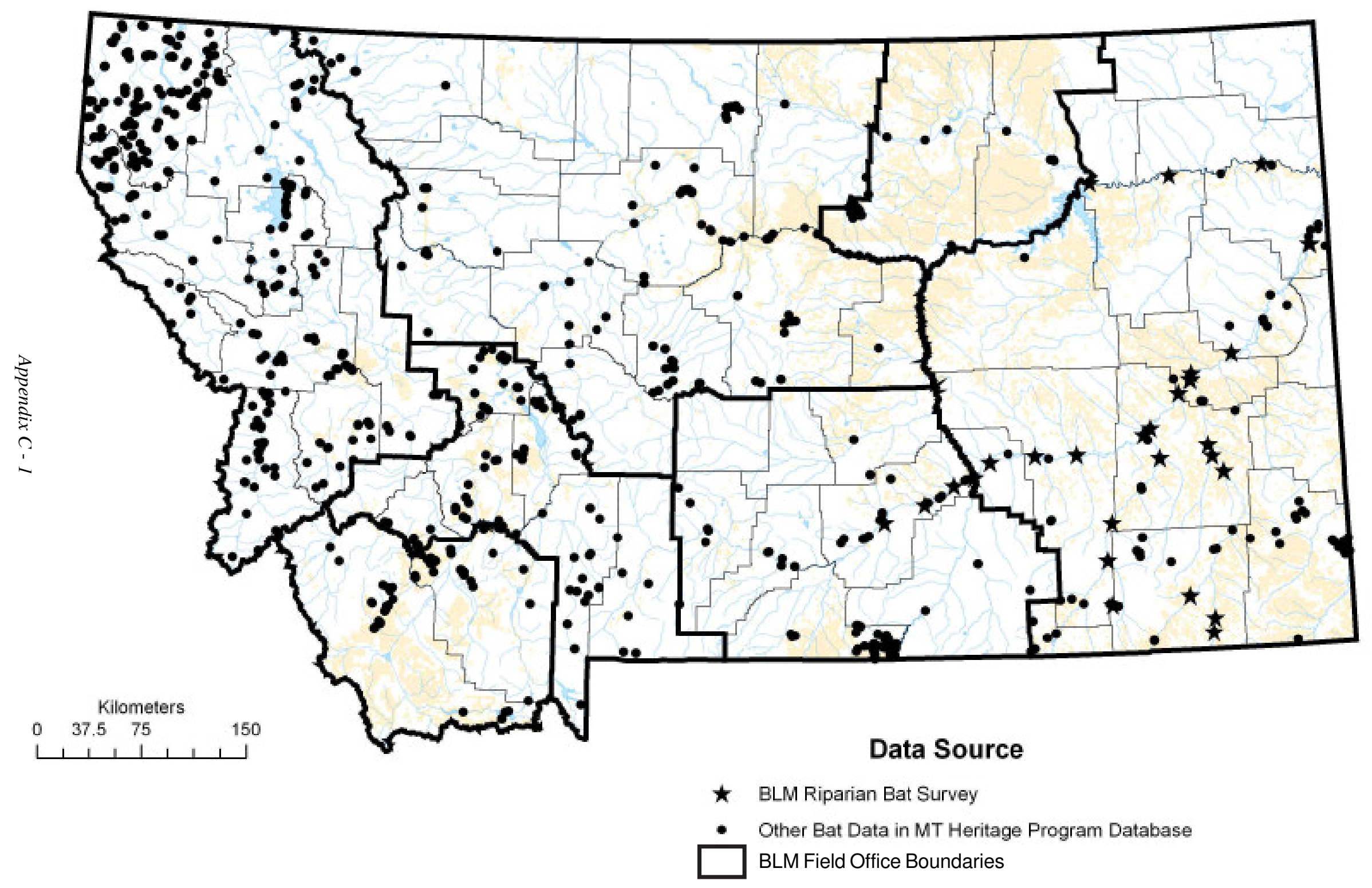




\section{Pallid Bat (Antrozous pallidus)}

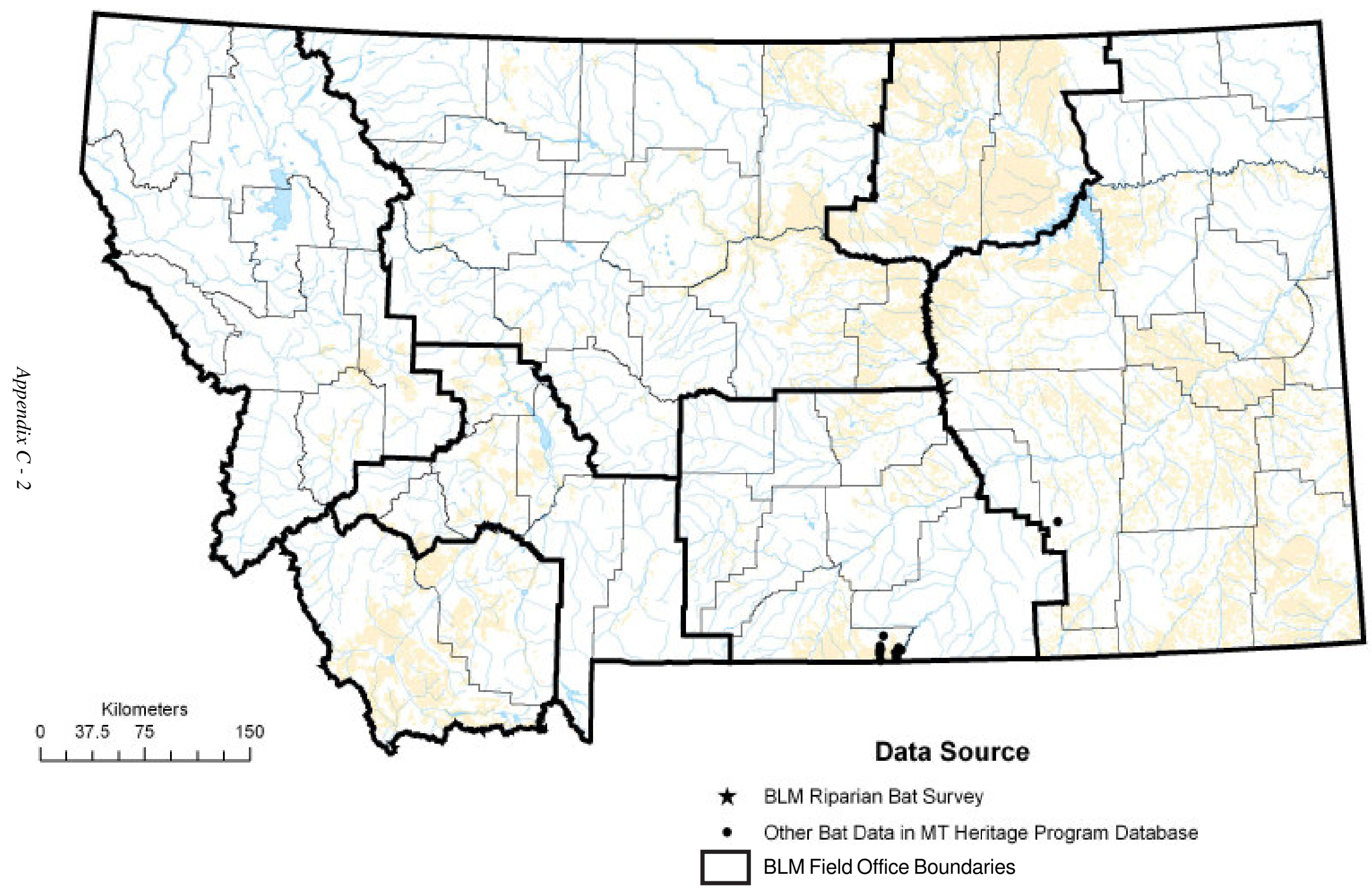


Townsend's Big-eared Bat (Corynorhinus townsendii)

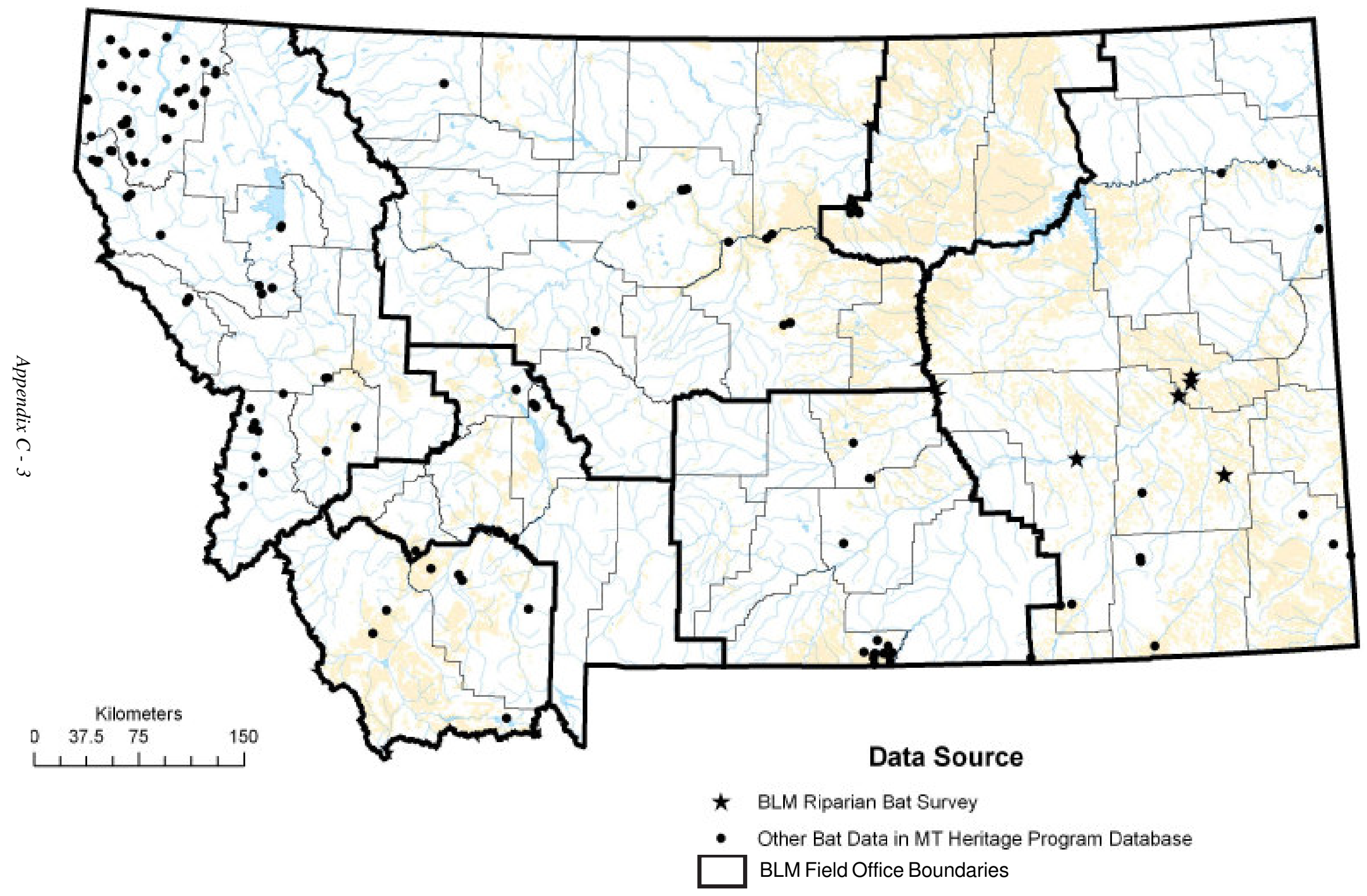




\section{Spotted Bat (Euderma maculatum)}

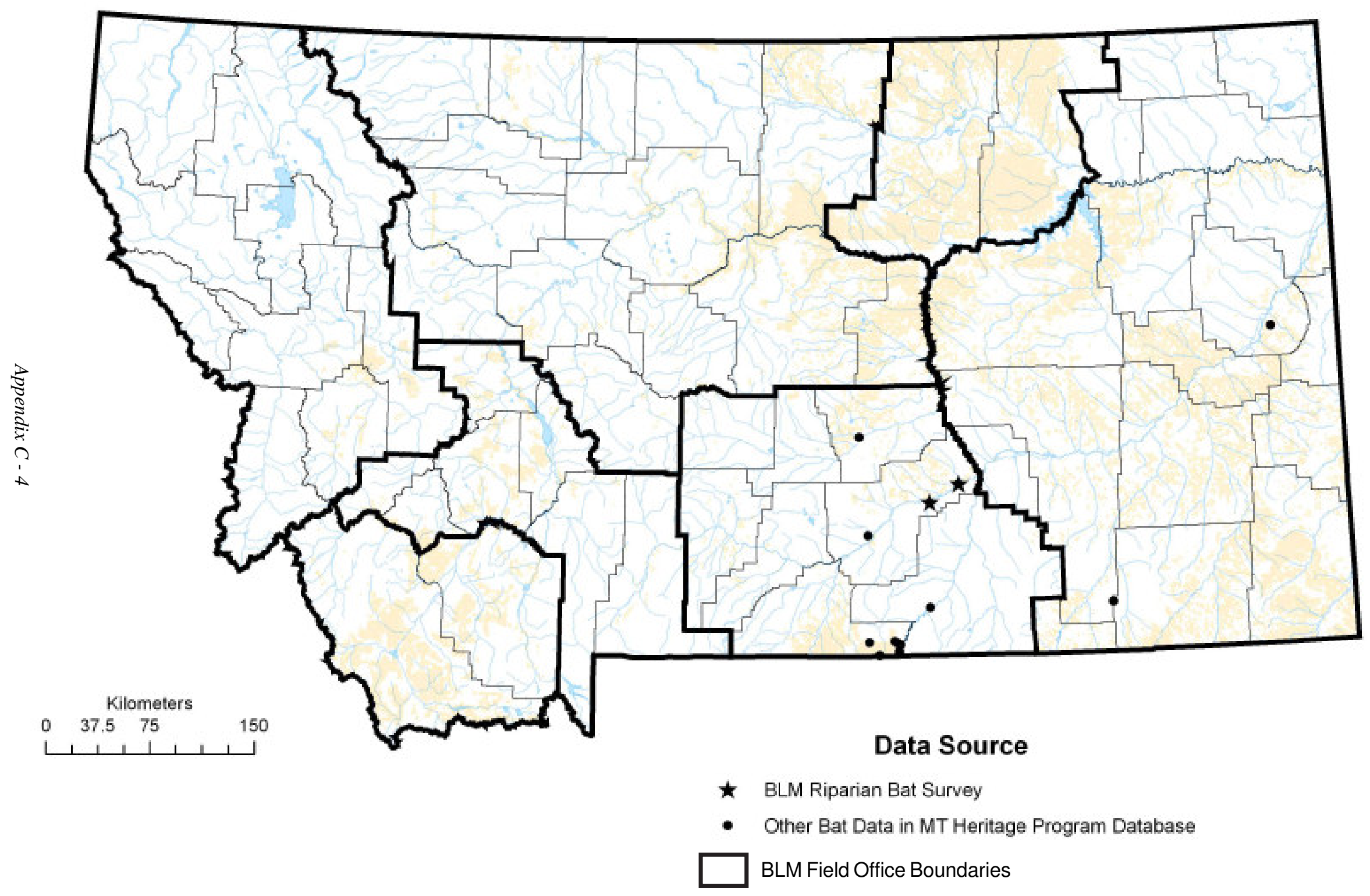


Hoary Bat (Lasiurus cinereus)

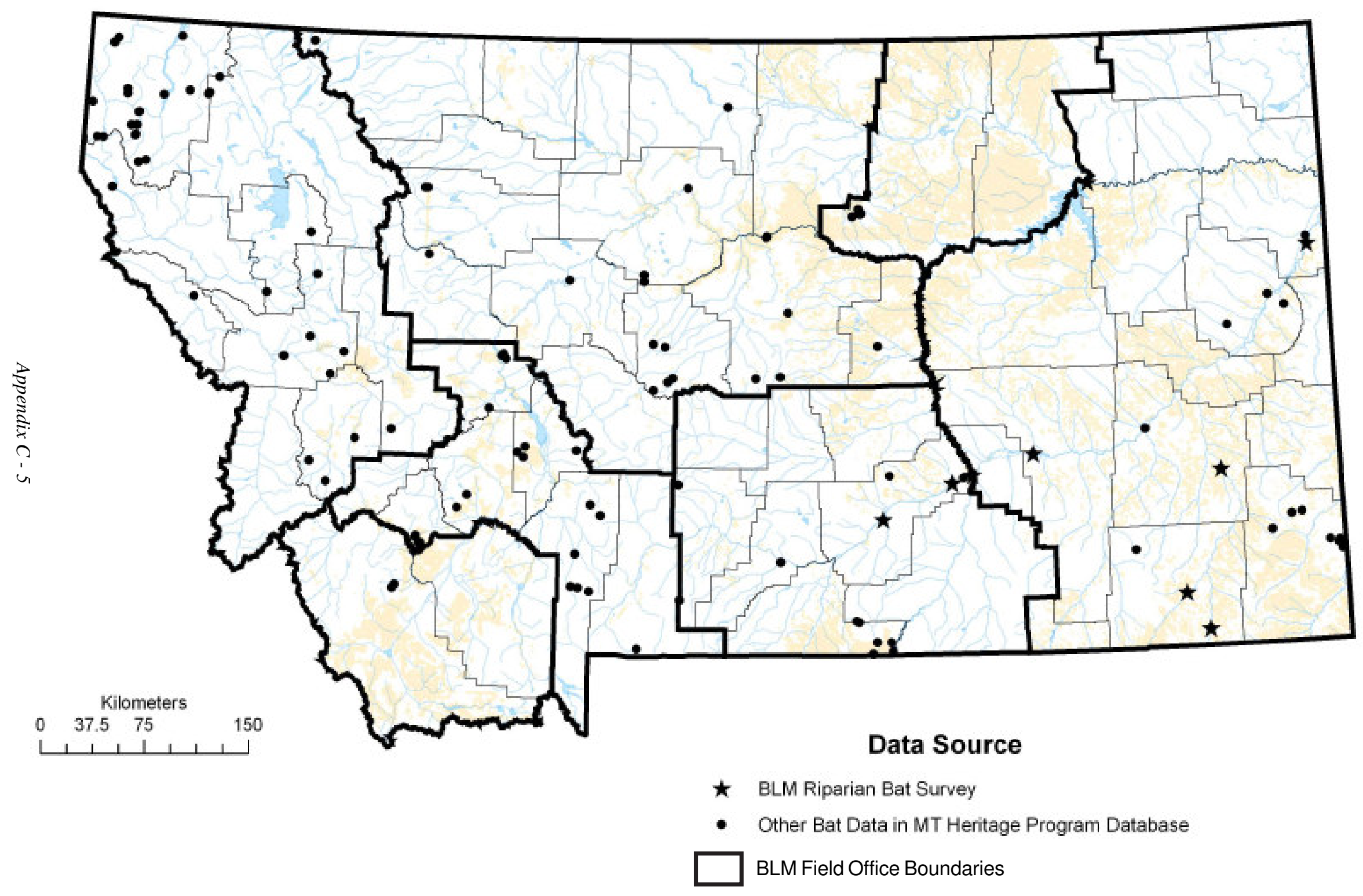




\section{Eastern Red Bat (Lasiurus borealis)}

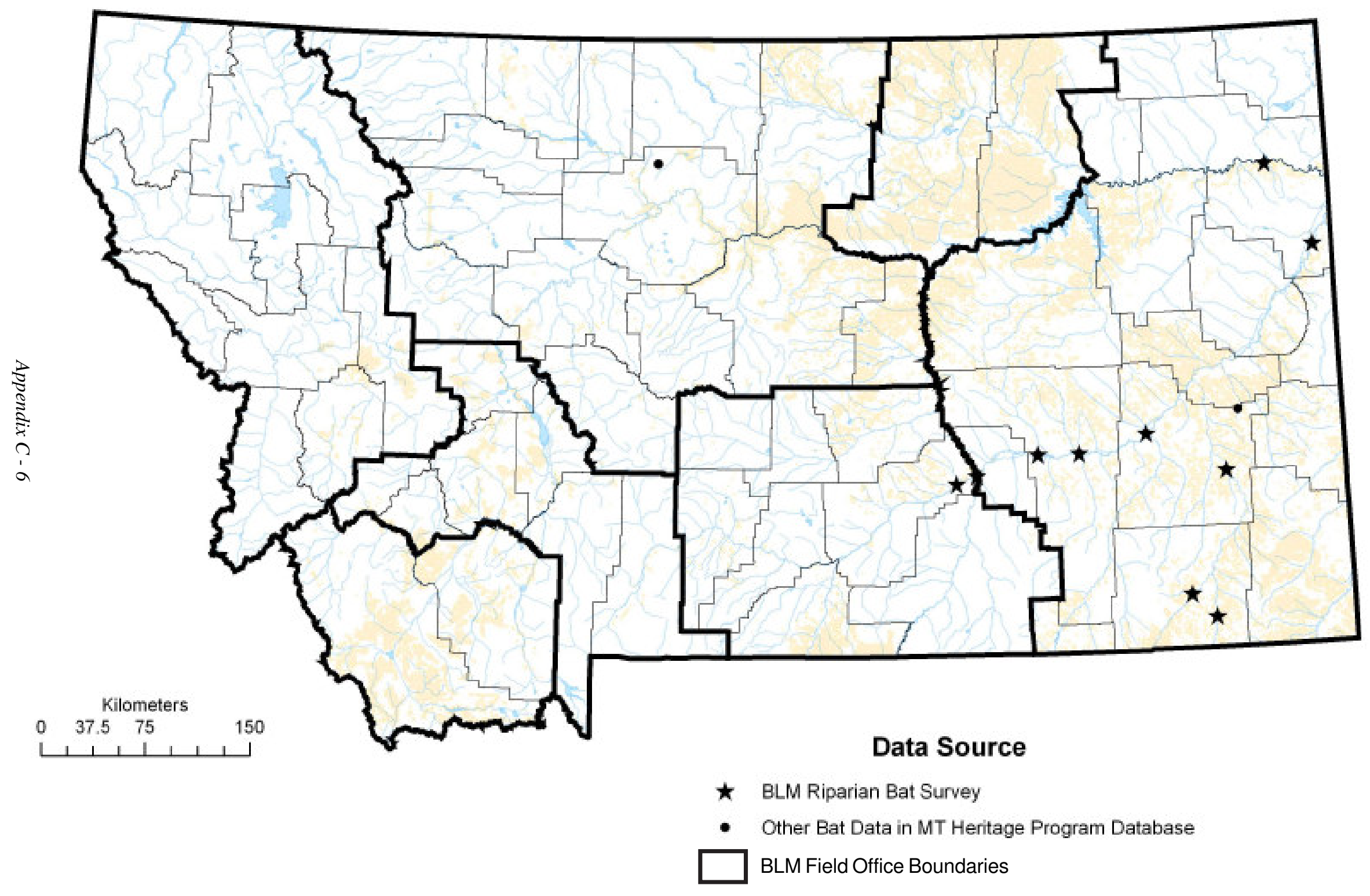


Big Brown Bat (Eptesicus fuscus)

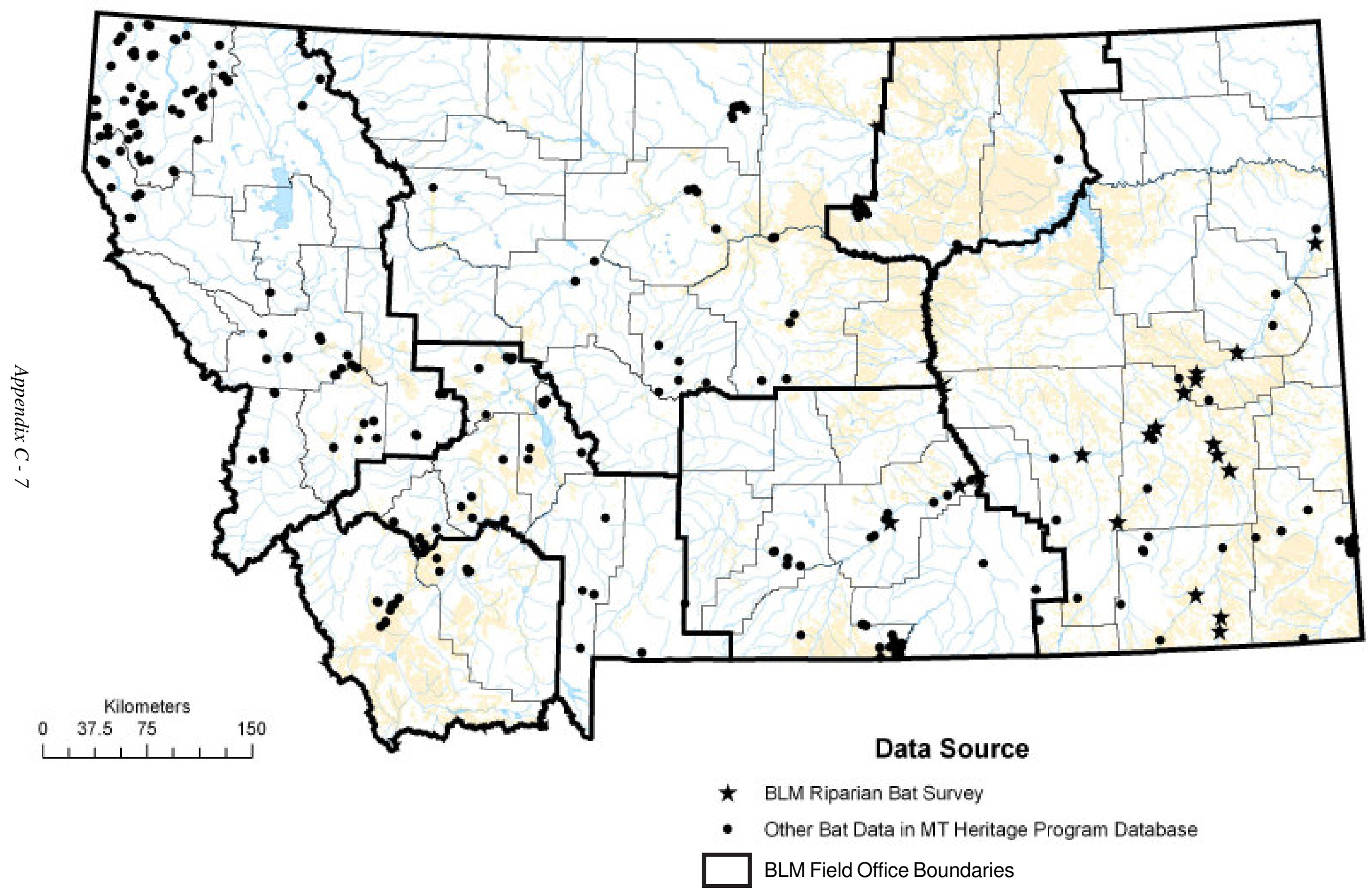


Silver-haired Bat (Lasionycteris noctivagans)

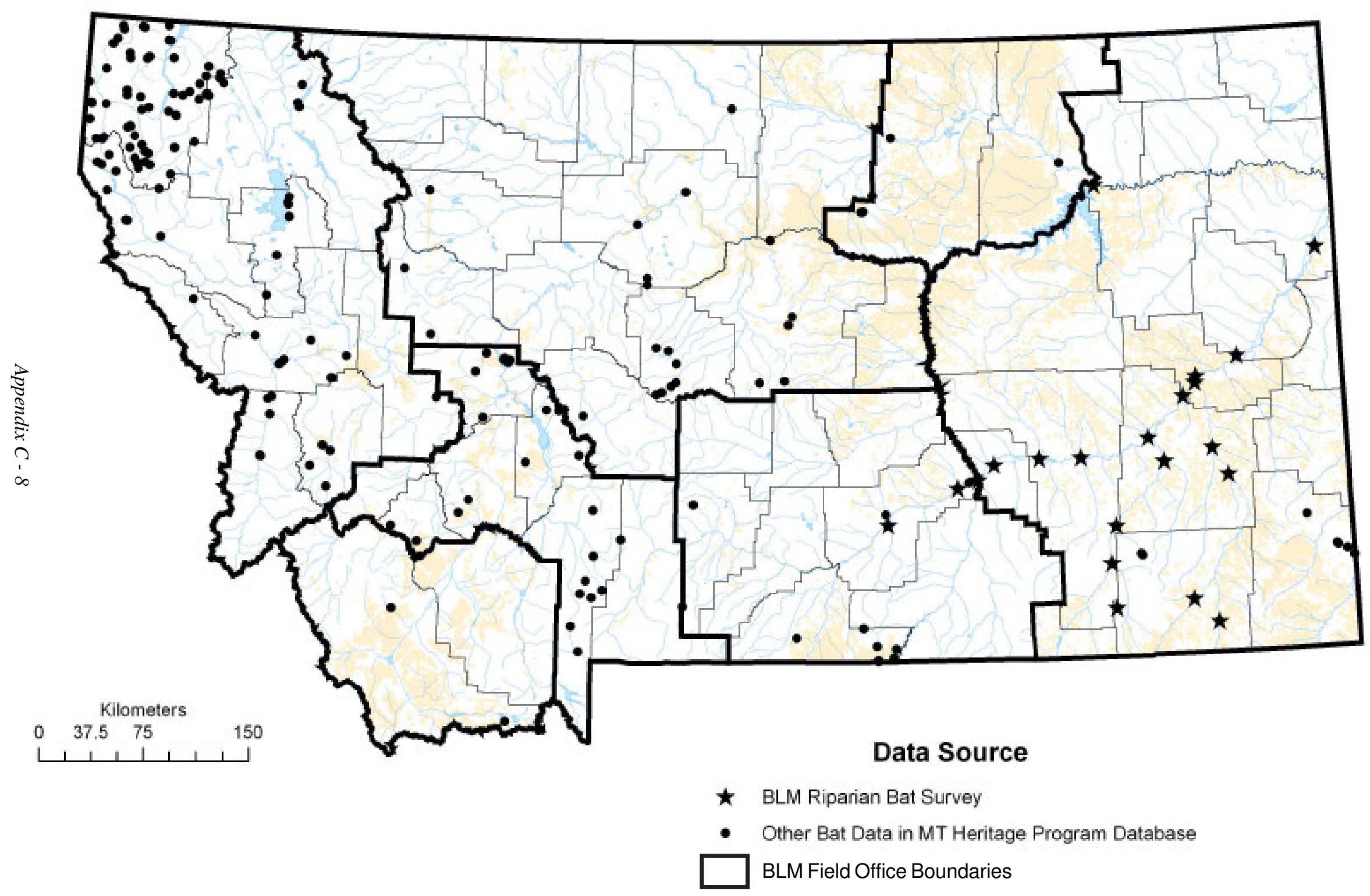


California Myotis (Myotis californicus)

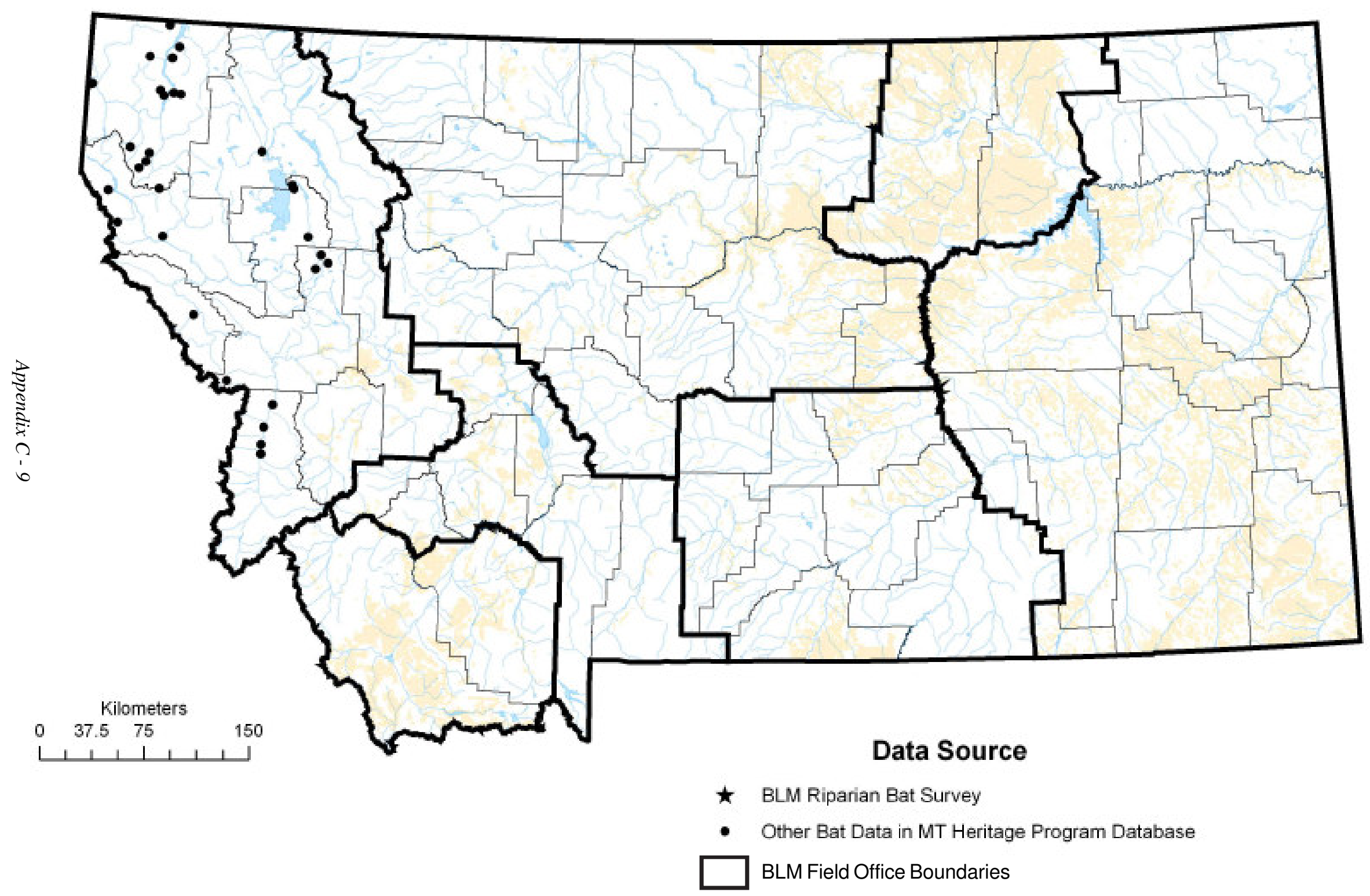


Western Small-footed Myotis (Myotis ciliolabrum)

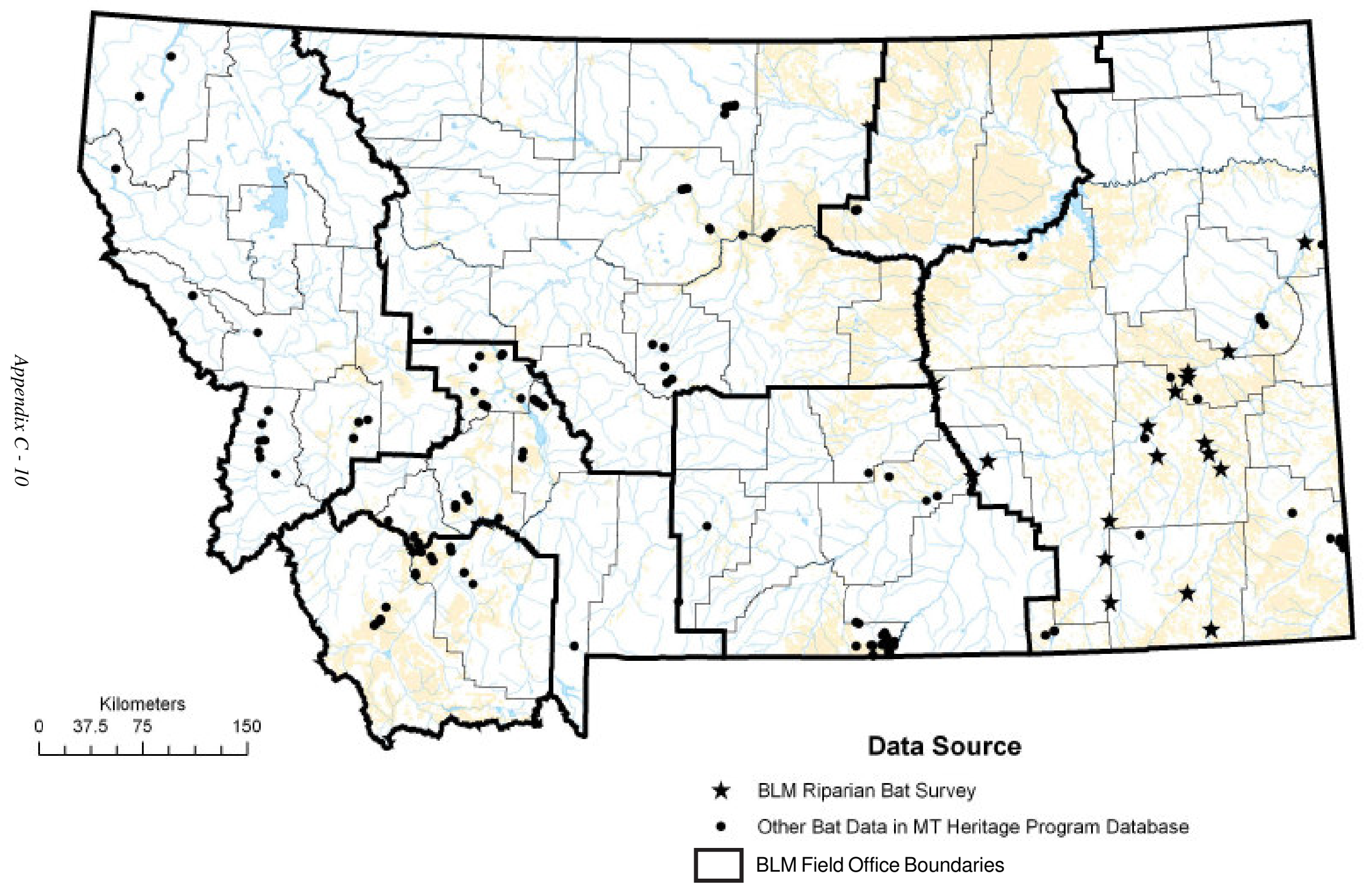




\section{Long-eared Myotis (Myotis evotis)}

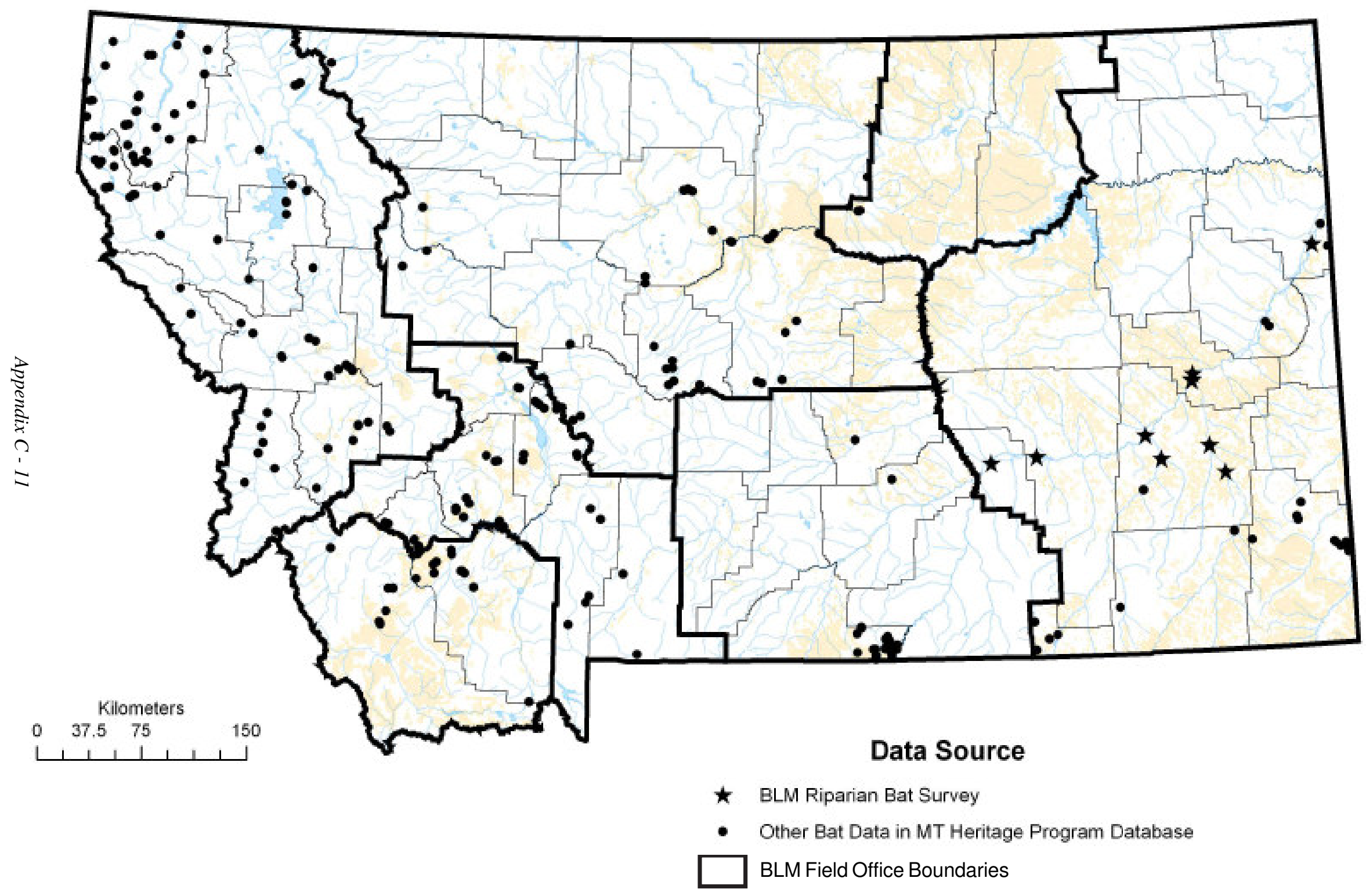




\section{Little Brown Myotis (Myotis lucifugus)}

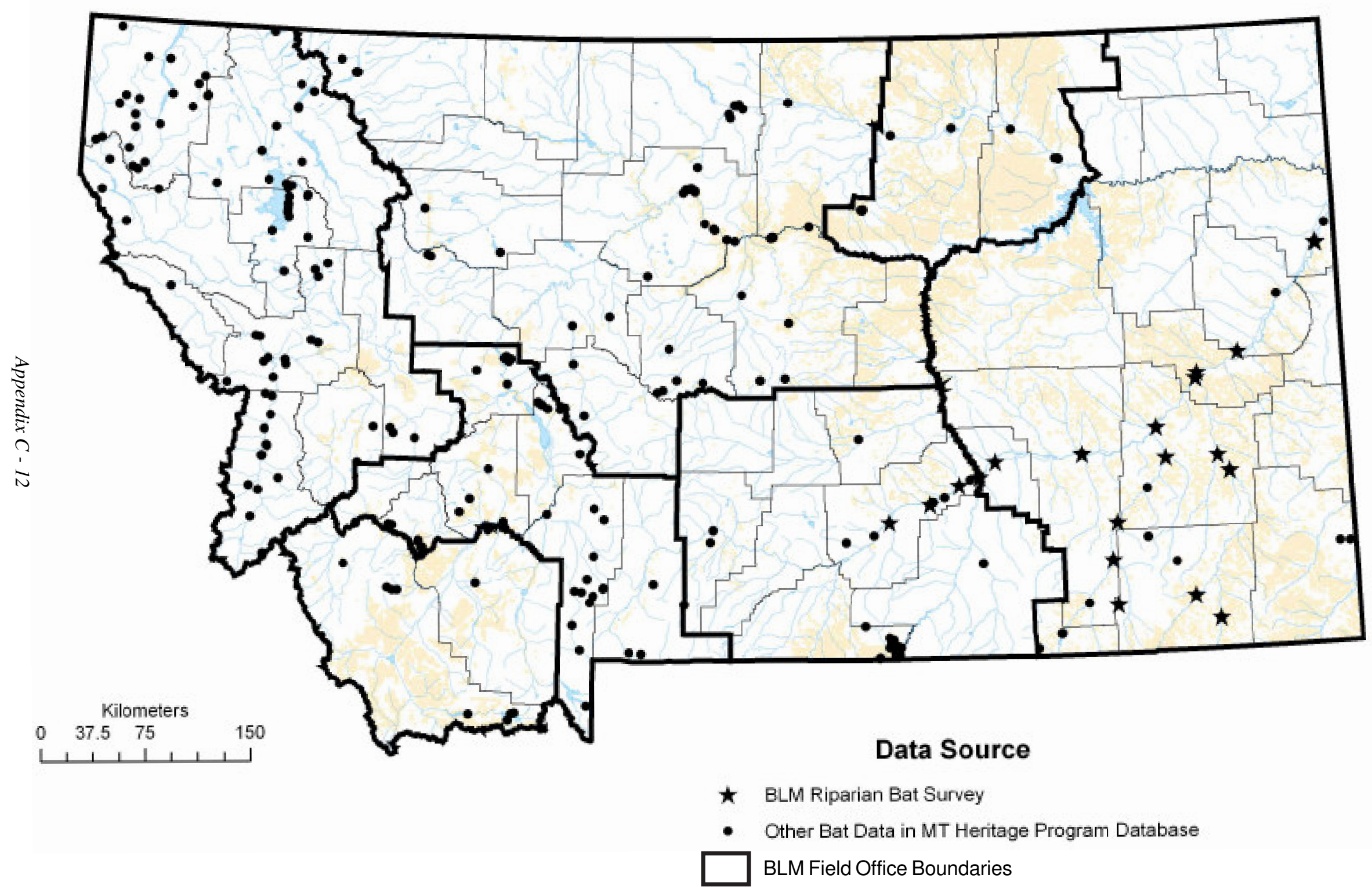


Northern Myotis (Myotis septentrionalis)

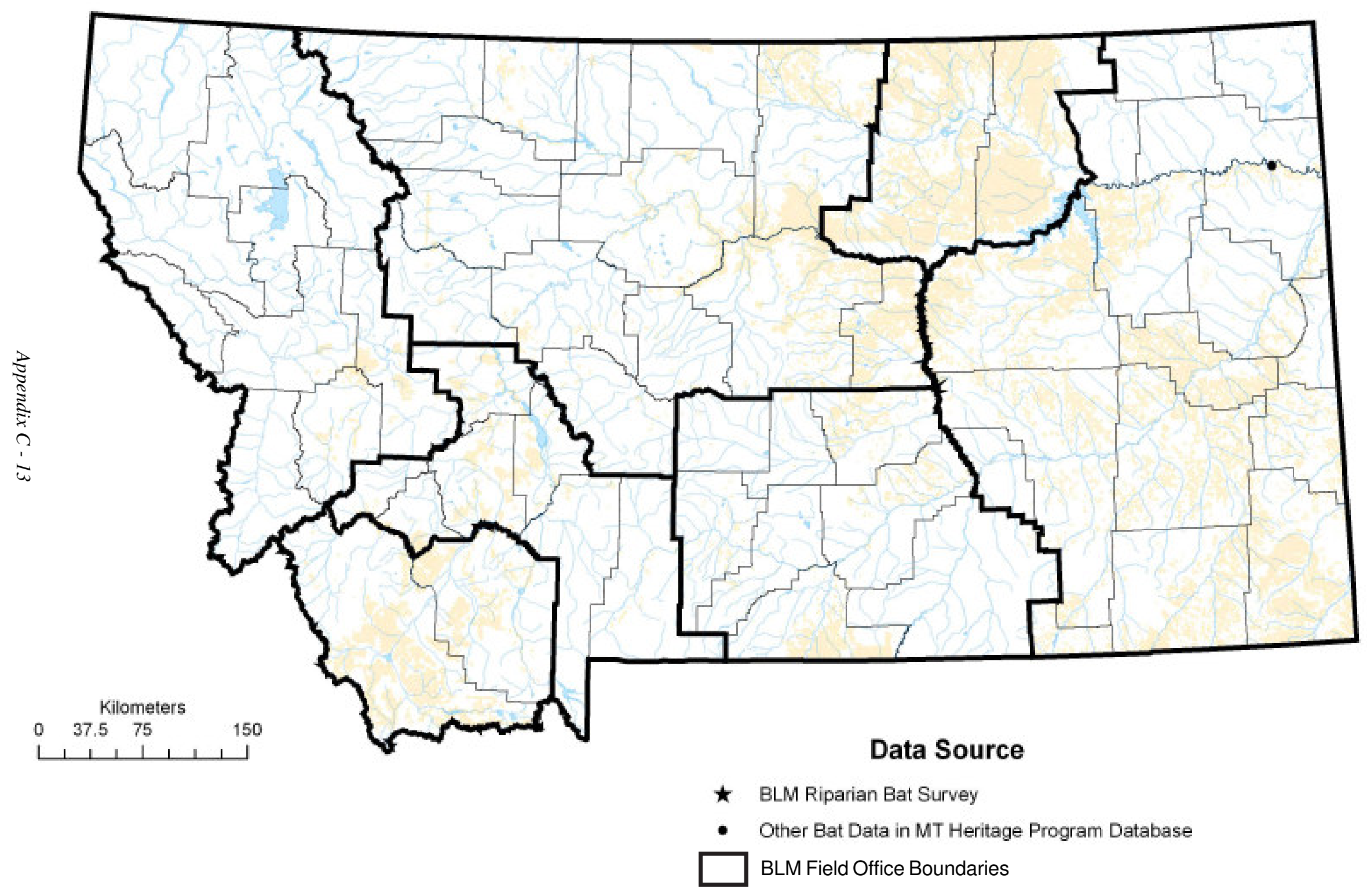


Fringed Myotis (Myotis thysanodes)

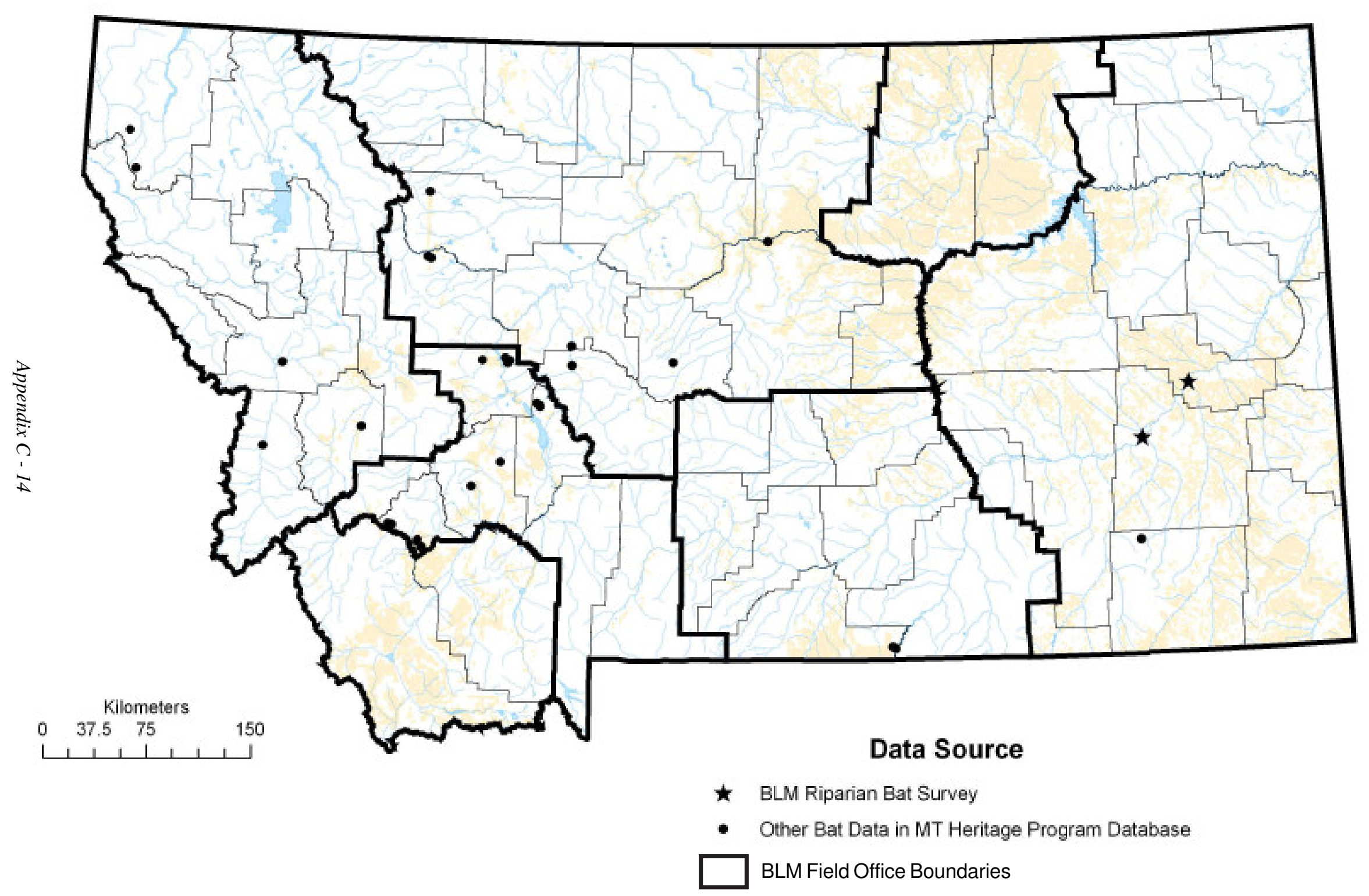


Long-legged Myotis (Myotis volans)

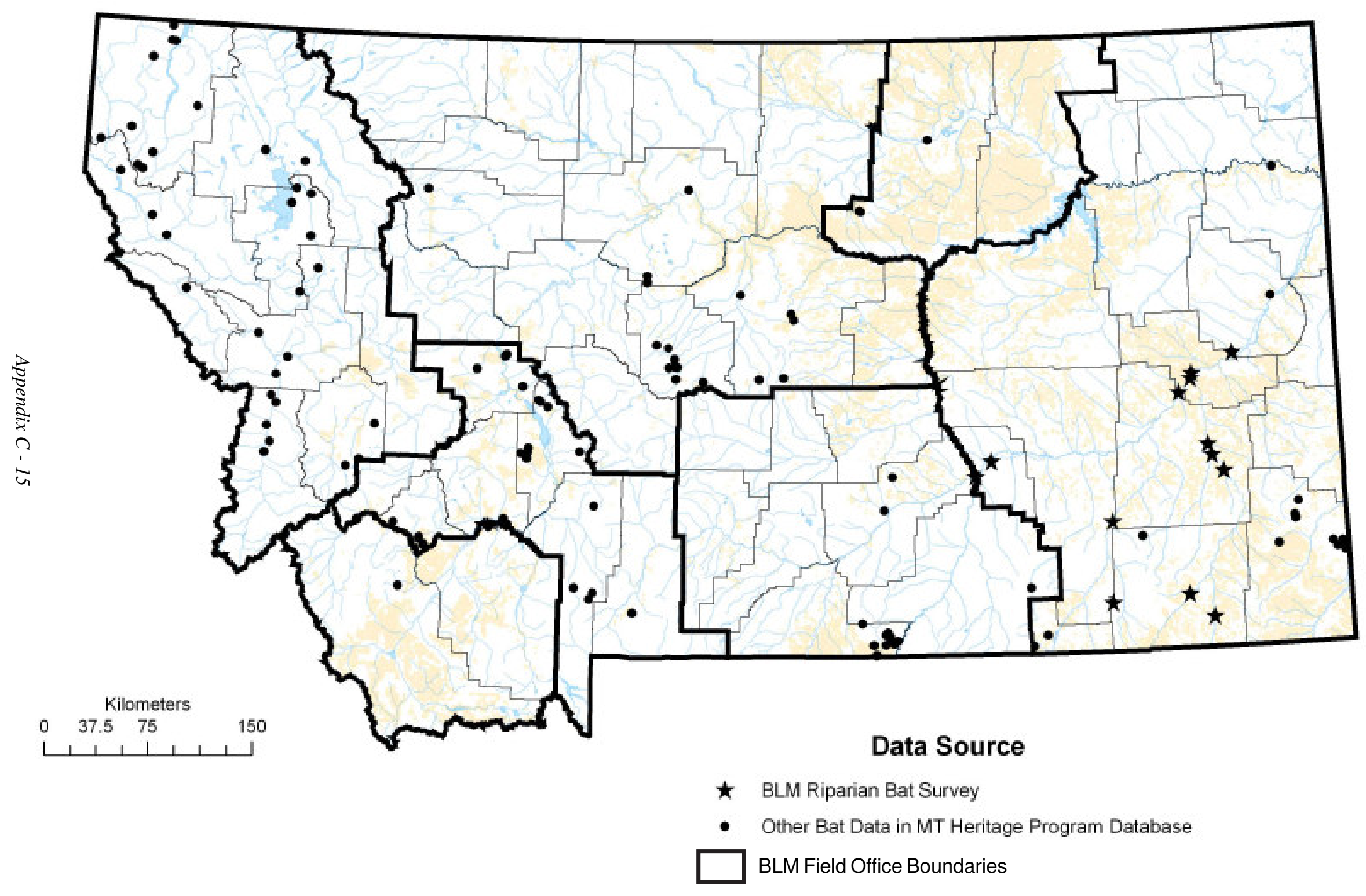


Yuma Myotis (Myotis yumanensis)

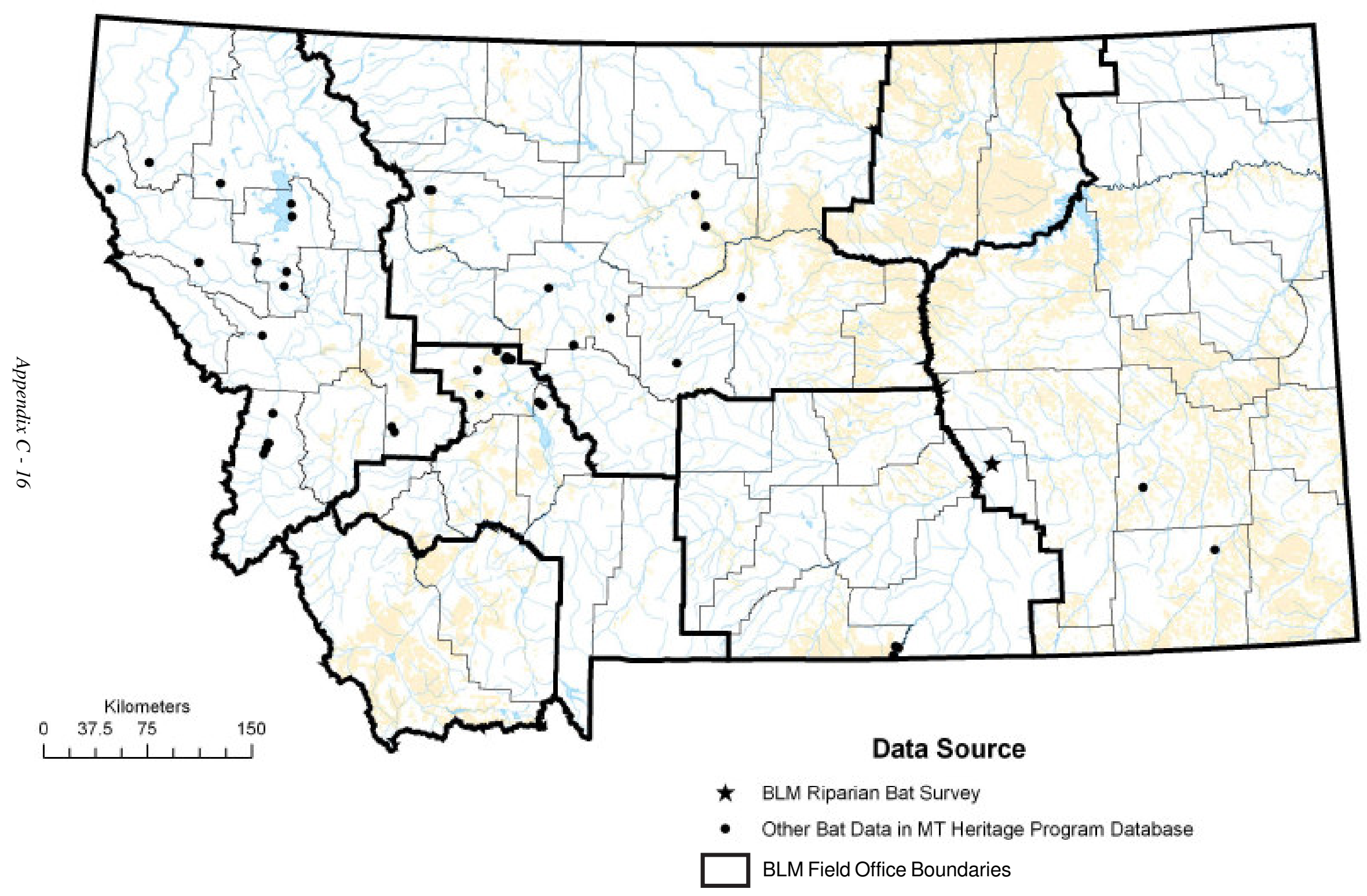

